Review

\title{
An Overview of Bioactive 1,3-Oxazole-Containing Alkaloids from Marine Organisms
}

\author{
Jinyun Chen ${ }^{1} \oplus$, Sunyan $\mathrm{Lv}^{1}{ }^{1}$, Jia Liu ${ }^{1} \oplus$, Yanlei Yu ${ }^{2}$, Hong Wang ${ }^{1}\left(\mathbb{D}\right.$ and Huawei Zhang ${ }^{1,3, *}$ \\ 1 School of Pharmaceutical Sciences, Zhejiang University of Technology, Hangzhou 310014, China; \\ chenjinyun07@163.com (J.C.); lvsunyan@163.com (S.L.); jliu3092@163.com (J.L.); hongw@zjut.edu.cn (H.W.) \\ 2 Collaborative Innovation Center of Green Pharmaceutics of Delta Yangzi Region, Zhejiang University of \\ Technology, Hangzhou 310014, China; yanleiyu@zjut.edu.cn \\ 3 Key Laboratory of Marine Fishery Resources Exploitment \& Utilization of Zhejiang Province, \\ Hangzhou 310014, China \\ * Correspondence: hwzhang@zjut.edu.cn
}

Citation: Chen, J.; Lv, S.; Liu, J.; Yu, Y.; Wang, H.; Zhang, H. An Overview of Bioactive 1,3-Oxazole-Containing Alkaloids from Marine Organisms.

Pharmaceuticals 2021, 14, 1274.

https://doi.org/10.3390/ph14121274

Academic Editors: Marianna Carbone and Maria Letizia Ciavatta

Received: 1 November 2021

Accepted: 1 December 2021

Published: 6 December 2021

Publisher's Note: MDPI stays neutral with regard to jurisdictional claims in published maps and institutional affiliations.

Copyright: (c) 2021 by the authors. Licensee MDPI, Basel, Switzerland. This article is an open access article distributed under the terms and conditions of the Creative Commons Attribution (CC BY) license (https:// creativecommons.org/licenses/by/ $4.0 /)$.

\begin{abstract}
Oxazole chemicals are a unique class of five-membered monocyclic heteroarenes, containing a nitrogen atom and an oxygen. These alkaloids have attracted extensive attention from medicinal chemists and pharmacologists owing to their diverse arrays of chemical structures and biological activities, and a series of 1,3-oxazole derivatives has been developed into therapeutic agents (e.g., almoxatone, befloxatone, cabotegravir, delpazolid, fenpipalone, haloxazolam, inavolisib). A growing amount of evidence indicates that marine organisms are one of important sources of 1,3-oxazole-containing alkaloids. To improve our knowledge regarding these marine-derived substances, as many as 285 compounds are summarized in this review, which, for the first time, highlights their sources, structural features and biological properties, as well as their biosynthesis and chemical synthesis. Perspective for the future discovery of new 1,3-oxazole compounds from marine organisms is also provided.
\end{abstract}

Keywords: 1,3-oxazole; alkaloid; marine natural product; bioactive property; marine organism; marine sponge; symbiotic microorganism

\section{Introduction}

Natural products and their structural analogs are an invaluable source of inspiration in drug design and development. 1,3-Oxazole chemicals are a unique class of five-membered monocyclic heteroarenes, containing a nitrogen atom and an oxygen atom, and usually possess a 2,4- or 2,5-substitution pattern with diverse chemical structures. It is noteworthy that these alkaloids display a wide range of biological properties, such as antibacterial, antifungal, anti-inflammatory, antimalarial, antioxidant, antiviral, cytotoxic, insecticidal, repellent activity, and an inhibitory effect on kinase, showcasing great therapeutic potential $[1,2]$. A growing amount of evidence indicates that 1,3-oxazole heterocycle is a fundamental structural motif found in marine natural products, which is putatively biosynthesized by the cyclodehydration and dehydrogenation of two amino acids (Figure 1) [3].

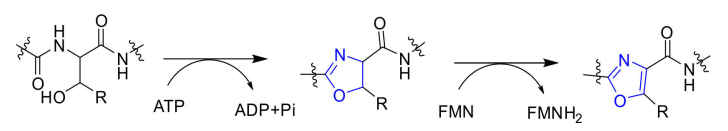

Figure 1. Proposed biosynthetic pathway for 1,3-oxazoles.

By an extensive and in-depth literature search using DNP (dictionary of natural products) and SciFinder tools, a total of 285 marine-derived 1,3-oxazole-containing compounds (1-285) were isolated and reported until 2020. Almost $80 \%$ of these substances were produced by animals (sponges, ascidian, nudibranch, hydrozoan, coral, sea hare and plume) 
followed by plants (cyanobacteria and red algae) and microorganisms (bacteria and fungi) (Figure 2). To better understand these marine-derived 1,3-oxazole substances and promote marine drugs, here, a systematic and comprehensive review is summarized for the first time. It highlights their biological sources, structural features and bioactivities, as well as biosynthesis and chemical synthesis by comparing with two recent review works, in which one mainly focuses on the biological activities of synthetic and natural oxazoles [4], and the other puts more emphasis on the sources, biological activities, structural features and chemical synthesis of natural oxazole-containing peptides [5]. On the basis of chemical structures, these 1,3-oxazole-based alkaloids are grouped into four major types including peptide, macrolide, polyketide and benzoxazole, and are respectively introduced herein. Detailed information for these natural products is supplied in the Supplementary Materials.

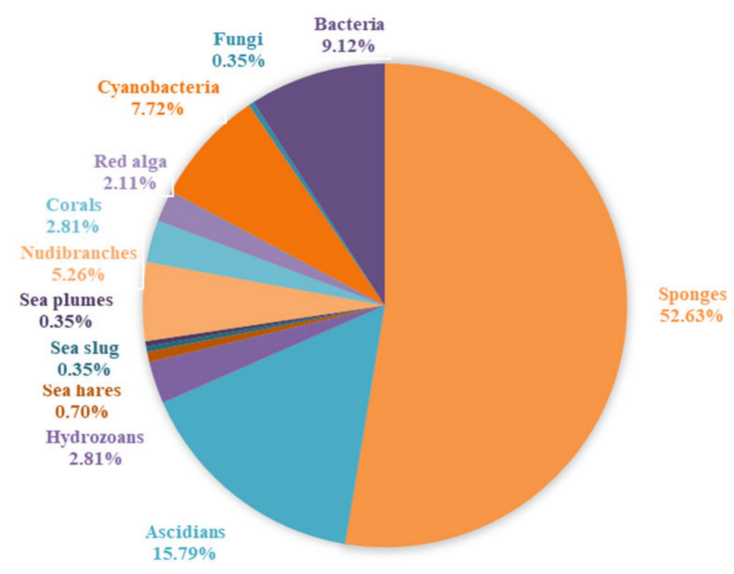

Figure 2. Percentage distribution of 1,3-oxazole-containing alkaloids from marine organisms.

\section{Peptides}

\subsection{Linear Peptides}

Marine algae and microorganisms are the major sources of linear peptides with the 1,3-oxazole motif. The chemical investigation of a red seaweed of Delesseriaceae from the coasts of north Dakar (Dakar, Senegal) successively led to the isolation of four new linear dipeptides almazoles A-D (1-4) (Scheme 1), in which each compound bears an unusual 2,5-disubstituted oxazole moiety [6-8]. Absolute structures of these algal metabolites were originally determined by biomimetic synthesis from $L$-tryptophan with $N, N$-dimethyl- $L$ phenylalanin, for which Robinson-Gabriel cyclization served as the key oxazole forming step [6]. Lately, almazole C (3) has been well prepared by a four-step synthesis, with a $32 \%$ overall yield through the Aza-Wittig reaction [9], while compound 4 was the first bioactive member of the almazole family, possessing potent antibacterial against Serratia marcescens and Salmonella typhi XLD [8], and its original structure was revised as 5-(3-indolyl)oxazole4-carboxylic acid by Horne and his coworkers [10]. Streptochlorin (5) and martefragin A (6) are another two novel 5-(3-indolyl)oxazole-containing alkaloids, respectively produced by marine strain Streptomyces sp. 04DH110 from the east sea of Korea [11] and the red algae Martensia fragilis collected off the coast of Uozu (Uozu, Japan) [12]. In addition to potent fungicidal activity against Pythium, Botrytis cinerea, Septoria tritici, Pyricularia Oryzae, Fusarium culmorum and Rhizoctonia solani, compound $\mathbf{5}$ displayed a strong inhibitory effect on angiogenesis by blocking NF- $\mathrm{KB}$ signaling, as well as human leukemia and normal liver cell lines with $\mathrm{IC}_{50}$ values of 1.05 and $10.9 \mu \mathrm{g} / \mathrm{mL}$, respectively $[11,13,14]$. It is noteworthy that one three-step synthesis of compound 5 had been readily achieved by sequential asmicester condensations and sulfanyl-Lithium exchange-trapping [15]. As a promising inhibitor of lipid peroxidation, compound $\mathbf{6}$ was firstly synthesized by Nishida and coworkers in 1998, and its absolute configuration was unambiguously determined as "S, "S [16]. Almazolone (7) had similar biogenetic features to compounds 1-4 and was purified from Senegal red alga Haraldiophyllum sp. [17]. 


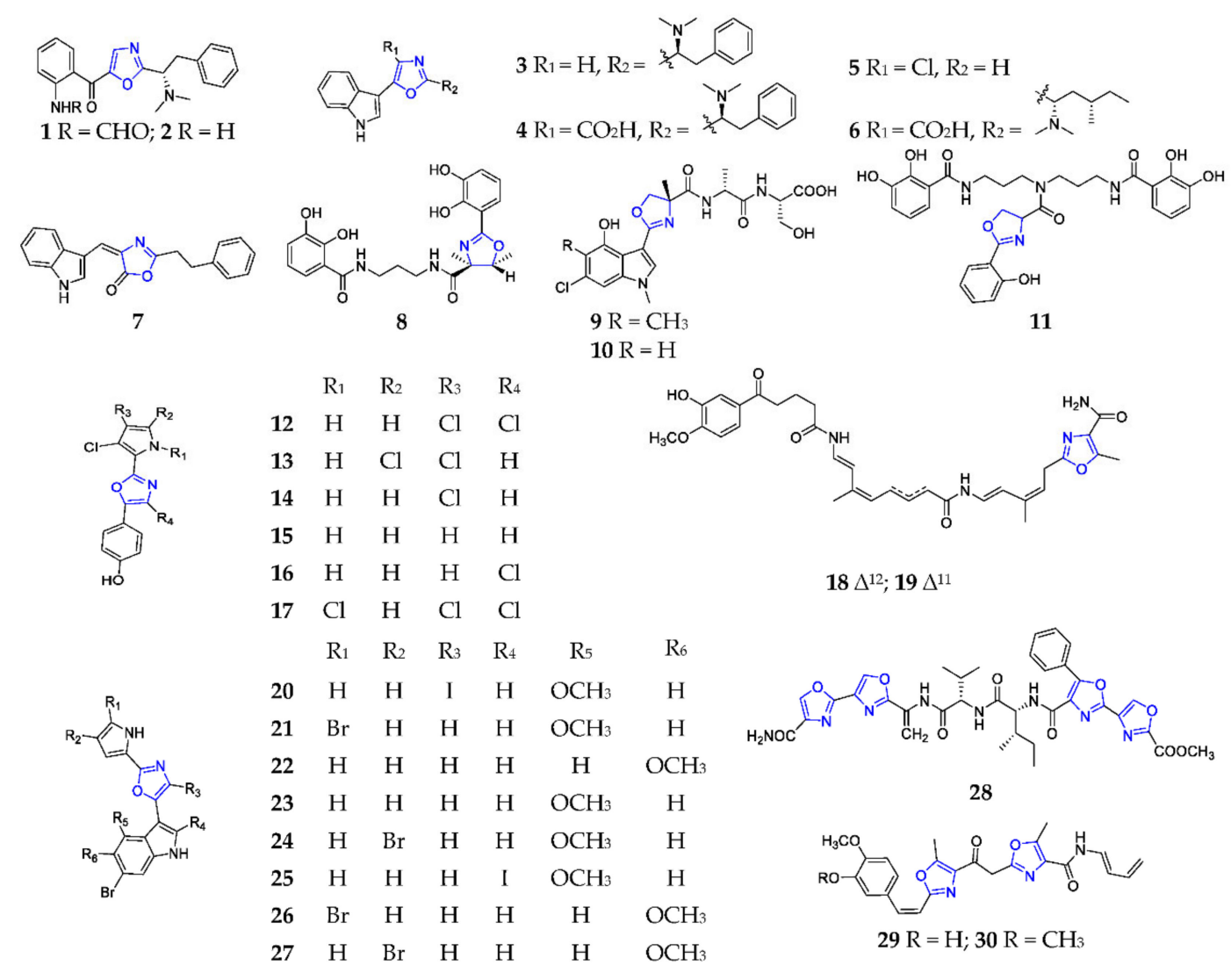

Scheme 1. Marine-derived 1,3-oxazole-containing linear peptides (1-30).

Co-culture of Serratia sp. and Shewanella sp. resulted in the production of serratiochelin A (8), which displayed antiproliferative activity against human melanoma cell lines and non-malignant lung fibroblasts, as well as antimicrobial activity toward Staphylococcus aureus [18]. Two new indole-containing peptides, JBIR-34 (9) and JBIR35 (10), were produced by one symbiotic strain Streptomyces sp. Sp080513GE-23 from Haliclona sp., and exhibited a potent DPPH radical scavenging capability with $\mathrm{IC}_{50}$ values of 1.0 and $2.5 \mathrm{mM}$, respectively [19]. The unique 4-methyloxazoline moiety was formed by a $\alpha$-methyl- $L$-serine from $D$-alanine and a 5,10-methylene-tetrahydrofolate by $\mathrm{FmoH}$ [20]. Nigribactin (11) was isolated as a new siderophore from marine Vibrio nigripulchritudo and was shown to enhance the expression of the spa encoding protein A [21]. Phorbazoles A-D (12-15) were a novel class of marine alkaloids, containing chlorinated pyrrole and 1,3-oxazole moieties from the Indo-Pacific sponge Phorbas aff. clathrata (Levi) [22]. Recently, the chemical preparation of phorbazole B (13) has been achieved by simple catalytic chlorination and iodization to protect the oxazole ring [23]. The first chemical analysis of the marine mollusc Aldisa andersoni, collected off Muttom coast, (Kanyakumari, India) afforded two new cytotoxic phorbazole analogs, 9-chloro-phorbazole $\mathrm{D}$ (16) and N1-methyl-phorbazole A (17), as well as phorbazoles A (2), B (13) and D (15) [24].

Two novel linear and achiral polyketide-peptides, ariakemicins A (18) and B (19), were obtained as an inseparable mixture from one marine gliding bacterium Rapidithrix sp., collected off the muddy land alongside the Ariake Inland Sea, and displayed selectively antimicrobial activities against Gram-positive bacteria (Brevibacterium sp., S. aureus, and Bacillus subtilis), and weak cytotoxicity against cancer cell lines A549 and BHK [25]. Breitfussins A-H (20-27) were the first marine natural products containing an indole-oxazolepyrrole framework from hydrozoan Thuiaria breitfussi inhabits in the Arctic ocean, and were found to excellently inhibit PIM1 and DRAK1 kinases [26,27]. Furthermore, breitfussin C (22) strongly exhibited a cytotoxic effect on cancer cell lines (MCF-7, HT-29, MOLT-4, MV-4-11 and MRC-5). One concise total synthesis of the halogen-rich dipeptides 20 and 21 
was created by Bayer and his coworkers in 2015, which consists of the palladium-catalyzed cross-coupling of indole and pyrrole on an oxazole core and selective lithiation/iodination of a common indole-oxazole fragment [28]. Mechercharmycin B (28) was a new linear peptide containing four 1,3-oxazole rings produced by the marine strain Thermoactinomyces $\mathrm{sp}$. YM3-251 from Mecherchar (Palau) [29]. Siphonazole (29) and dimethoxy analog (30) were the first naturally occurring substances that incorporated oxazole subunits connected by a two-carbon tether from a marine microbe Herpetosiphon sp., and exhibited selective cytotoxicity to human breast cancer HTB-129 and acute T cell leukemia TIB-152 [30]. The first chemical synthesis of $\mathbf{2 9}$ was achieved in 2007 through the preparation of an oxazole ring using rhodium carbene, and the installation of the pentadienyl amino side-chain [31].

\subsection{Monocyclic Peptides}

\subsubsection{Pentapeptides}

To the best of our knowledge, the marine sponge genus Theonella is the most common and important producer of 1,3-oxazole-containing pentapeptides. An inseparable mixture of three dimeric cyclic pentapeptides, nazumazoles A-C (31-33) (Scheme 2), was obtained from the aqueous alcoholic extract of Theonella swinhoei, collected from Hachijo Island (Tokyo, Japan), and exhibited a potent cytotoxicity against P388 murine leukemia cells with an $\mathrm{IC}_{50}$ value of $0.83 \mu \mathrm{M}$ [32]. Subsequently, three new monomeric analogs, nazumazoles D-F (34-36), were purified from the same specimen and shown to remarkably inhibit chymotrypsin with $\mathrm{IC}_{50}$ values of 2,3 and $10 \mu \mathrm{M}$, respectively [33]. All absolute configurations of the amino acid residues in compounds 31-36 were unambiguously determined by Marfey's method. Seven 2-bromotryptophan-containing pentapeptides, orbiculamide A (37), keramamides B-E (38-41), M (42), and N (43) from an Okinawan Theonella sp., displayed, in vitro, a strongly cytotoxic effect on cell lines P388, LI210 and KB [34]. Discobahamins A (44) and B (45) were isolated from a deep-water marine sponge Discodermia sp. collected off Goulding Cay (Goulding Cay, Bahamas), and were shown to have weak antifungal activity against Candida albicans [35].

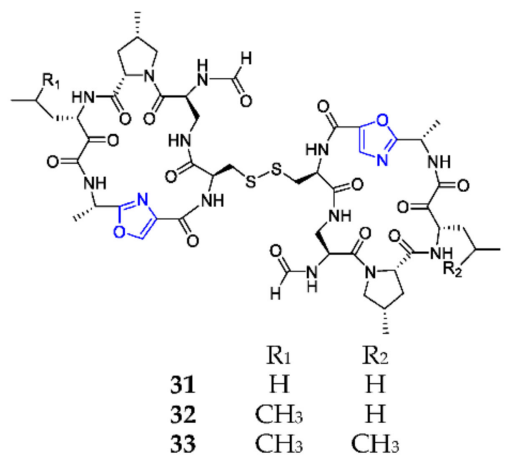

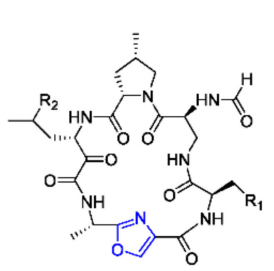

$\mathrm{R}_{1} \quad \mathrm{R}_{2}$

$34 \mathrm{CH}_{3} \quad \mathrm{H}$

$35 \quad \mathrm{OH} \quad \mathrm{H}$

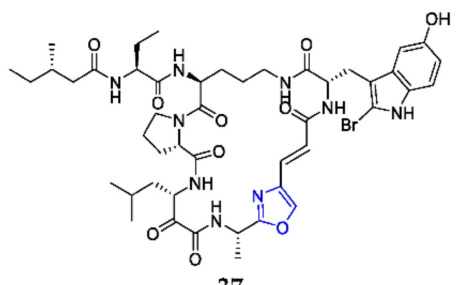

$\mathrm{OH} \quad \mathrm{CH}_{3}$

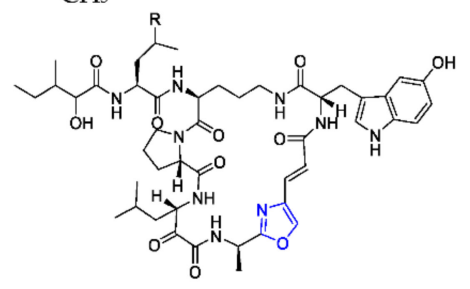

$44 \mathrm{R}=\mathrm{H} ; 45 \mathrm{R}=\mathrm{CH}_{3}$

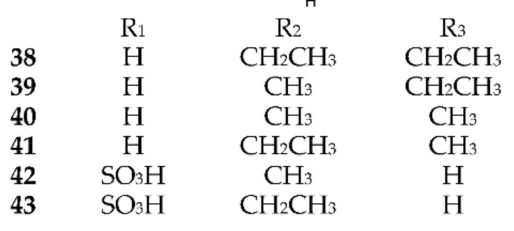

Scheme 2. Marine-derived 1,3-oxazole-containing monocyclic pentapeptides (31-45). 


\subsubsection{Hexapeptides}

Ascidians of the genera Lissoclinum and Didemnum are prolific producers of cyclic hexapeptides with 1,3-oxazole moieties and thiazole, thiazoline or oxazoline rings. During the period from 1989 to 2017, a total of thirteen hexapeptides, bistratamides A-N (46-58) (Scheme 3), had been found in ascidian L. bistratum. The structure-activity relationship (SAR) analysis indicated that bistratamides containing two thiazole rings possessed stronger cytotoxic activity than others containing one thiazole ring and/or one oxazole ring [36-40]. Westiellamide (59) and dendroamides A-C (60-62) are new bistratamide analogs derived from blue-green algae. Compound 59 exhibited moderate cytotoxicity against $\mathrm{KB}$ and LoVo cell lines at $2 \mu \mathrm{g} / \mathrm{mL}$ and $\mathbf{6 0}$ showed excellent activity toward multidrug resistant tumors [41,42]. Chemical study of the extracts of ascidian Didemnum molle collected in Madagascar afforded didmolamide A (63), with a mild cytotoxic effect on tumor cell lines A549, HT29 and MEL28 [43]. Bertram and his coworkers firstly invented a novel method to synthesize bistratamides and didmolamides by mediating the coupling reaction of azole amino acids via FDPP-i-Pr2NEt [44].

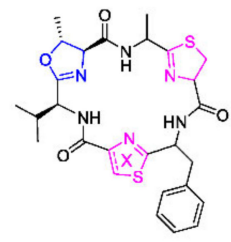

$46 \mathrm{X}=$ thiozoline

$47 X=$ thiozole

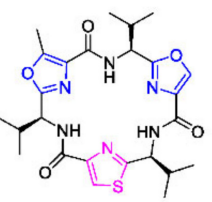

53

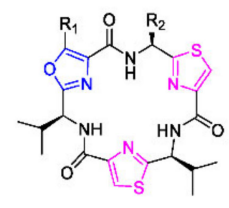

$48 \mathrm{R}_{1}=\mathrm{H}_{1} \mathrm{R}_{2}=\mathrm{CH}_{3}$

$49 \mathrm{R}_{1}=\mathrm{CH}_{3}, \mathrm{R}_{2}=\mathrm{CH}\left(\mathrm{CH}_{3}\right)$

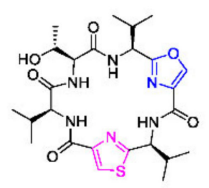

54

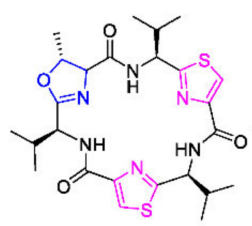

50

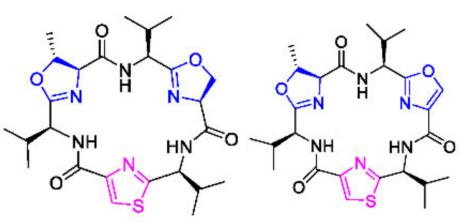

51

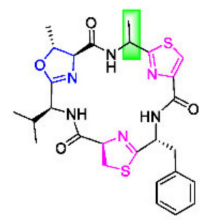

$55 D ; 56 L$

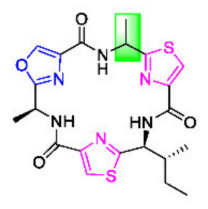

$57 L ; 58 D$

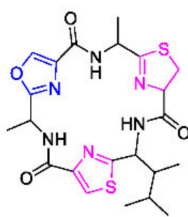

64

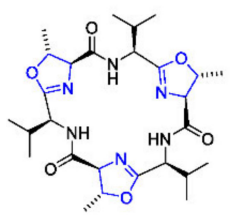

59

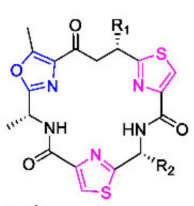

$60 \mathrm{R}_{1}=\stackrel{\xi_{1}}{ } \backslash, \mathrm{R}_{2}=\mathrm{CH}_{3}$

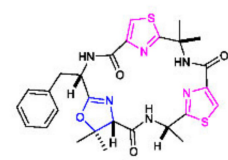

63

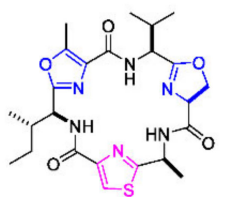

65

$61 \mathrm{R}_{1}=\mathrm{CH}_{3}, \mathrm{R}_{2}=$ '

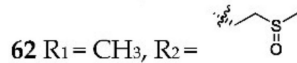

Scheme 3. Marine-derived 1,3-oxazole-containing monocyclic hexapeptides (46-65).

Dolastatins E (64) and I (65) were obtained from the Japanese sea hare Dokizbelh auriculariu, and displayed inconspicuous cytotoxic activity against HeLa $S_{3}$ cells $[45,46]$. The former substance structurally consisted of one $L$-alanine, one $D$-alanine, one $D$-cysteine, one allo- $D$ isoleucine, one serine and one cysteine [47], and the later was formed by a $N$-Boc-L-valine and $N$-Boc- $L$-serine [48]. One cytotoxic 1,3-oxazole-containing hexapeptide, leucamide A (66) (Scheme 4), was produced by an Australian sponge Leucetta microraphis [49], and its uniquely mixed 4,2-bisheterocycle tandem pair provided antiviral activity through a specific interaction with DNA/RNA or other targets [50]. Furthermore, the construction of the 4,2-bisheterocycle tandem pair was successfully forged by a diethylaminosulfur trifluoride (DAST)-mediated cyclization of $\beta$-hydroxy amide in the first total synthesis [51]. 


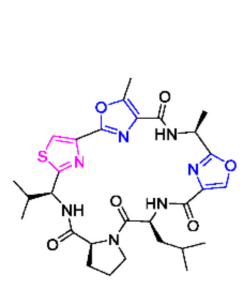

66

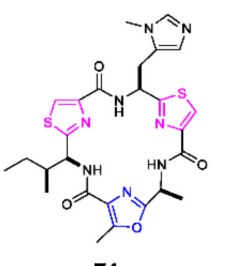

74

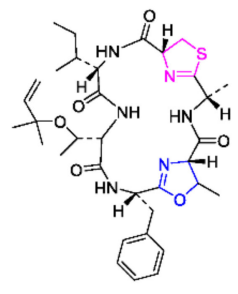

67

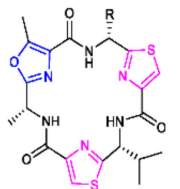

$68 \mathrm{R}=\mathrm{CH}_{3}$

$69 \mathrm{R}=(R)-\mathrm{CHOHCH}_{3}$

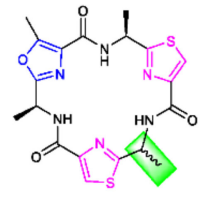

$70 \mathrm{D} ; \mathbf{7 1} L$

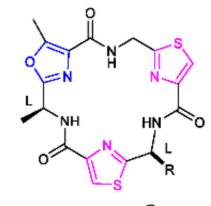

$72 \mathrm{R}=\sim^{\mathrm{S}}-\mathrm{CH}_{3}$

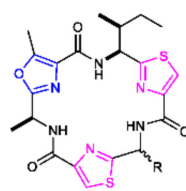

$75 \mathrm{R}=\mathrm{CH}_{3}$

$76 \mathrm{R}=\mathrm{H}$

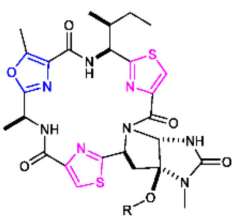

77

78

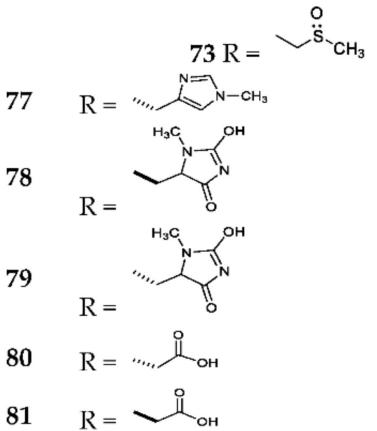

Scheme 4. Marine-derived 1,3-oxazole-containing monocyclic hexapeptides (66-81).

One novel cyclic hexapeptide, comoramide A (67), produced by the ascidian Didemnum molle and collected at Dzaoudzi Mayotte, was found to exhibit mild cytotoxicity against tumor cells A549, HT29 and MEL-28 [52]. Bioassay-guided fractionation of the marine cyanobacterium Oscillatoria sp., collected off Buenaventura Bay, led to the isolation of two antimalarial agents, venturamides A (68) and B (69), which were chemically synthesized using an efficient one-pot method with respective yields of $32.7 \%$ and $30.7 \%$ [53]. Tenuecyclamides A-D (70-73) were purified from the cyanobacterium $N$. spongiaeforme var. tenue, of which $\mathbf{7 0}, \mathbf{7 2}$ and $\mathbf{7 3}$ had an inhibitory effect on the sea urchin embryos' division with an $\mathrm{ED}_{100}$ of $10.8,9.0$ and $19.1 \mu \mathrm{M}$, respectively [54]. The stereochemistry of $\mathbf{7 0}$ and $\mathbf{7 1}$ was established through the solid-phase assembly of heterocyclic amino acids in 2004 [55]. Microcyclamides are one class of cyclic hexapeptides formed by the ribosomal pathway [56]. Chemical study of the cyanobacterium Microcystis aeruginosa afforded eight cytotoxic microcyclamide derivatives $(74-81)[57,58]$.

\subsubsection{Heptapeptides}

Using the heat shock method, one novel 1,3-oxazole-containing heptapeptide, cyanothecamide C (82) (Scheme 5), was produced by the marine cyanobacteria Cyanothece sp. PCC 7425 at $37^{\circ}$ for $24 \mathrm{~h}$ [59]. Cyclodidemnamide (83) was derived from the marine ascidian Didemnum molle, collected on the Philippine Islands, and exhibited weak cytotoxicity towards human colon tumor cells [60]. Two isomers, (cis, cis)-ceratospongamide (84) and (trans, trans)-ceratospongamide (85), were obtained from the Indonesian red algae Ceratodictyon spongiosum and symbiotic sponge Sigmadocia symbiotica, of which the latter possessed a potent anti-inflammatory effect with an $\mathrm{ED}_{50}$ value of $32 \mathrm{nM}$ [61]. Chemical investigation of the ascidian Lissoclinum patella resulted in the sequential isolation of 11 cytotoxic heptapeptides, including lissoclinamides (86-95) and ulicyclamide (96) [62-67]. SAR analysis indicated that cytotoxic effects of 89,90 and 92 were obviously reduced if the thiazoline ring was replaced by oxazoline, and that of 92 was significantly increased by replacing oxazoline in the macrocycle with thiazoline [68]. 

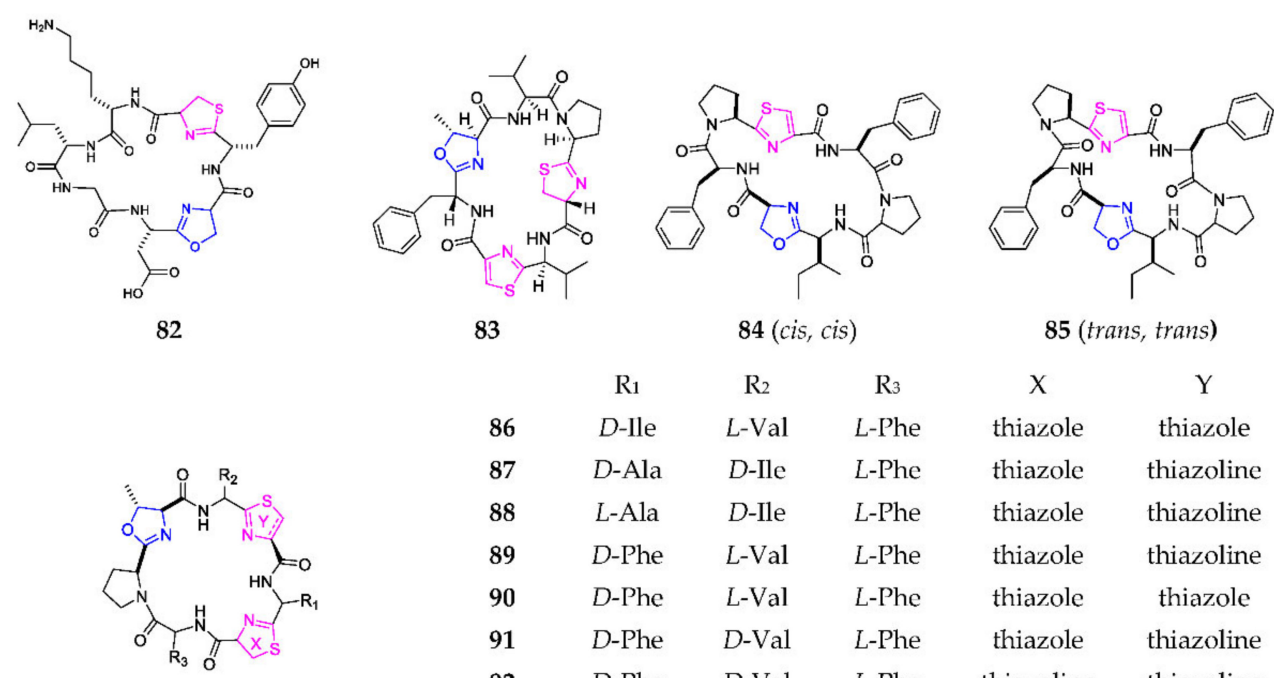

83

\begin{tabular}{|c|c|c|c|}
\hline & $\mathrm{R}_{1}$ & $\mathrm{R}_{2}$ & $\mathrm{R}_{3}$ \\
\hline 86 & $D$-lle & $L$-Val & $L$-Phe \\
\hline 87 & D-Ala & $D$-Ile & $L$-Phe \\
\hline 88 & L-Ala & $D$-Ile & $L$-Phe \\
\hline 89 & $D$-Phe & $L$-Val & $L$-Phe \\
\hline 90 & $D$-Phe & $L$-Val & $L$-Phe \\
\hline 91 & D-Phe & $D$-Val & L-Phe \\
\hline 92 & D-Phe & $D$-Val & L-Phe \\
\hline 93 & Phe & Val & $L$-Phe \\
\hline 94 & $D$-Val & L-Пе & D-Phe \\
\hline 95 & $L$-Пle & L-Пle & D-Phe \\
\hline 96 & D-Ala & L-Пle & L-Phe \\
\hline
\end{tabular}

85 (trans, trans)

$\begin{array}{cc}\text { X } & \text { Y } \\ \text { thiazole } & \text { thiazole } \\ \text { thiazole } & \text { thiazoline } \\ \text { thiazole } & \text { thiazoline } \\ \text { thiazole } & \text { thiazoline } \\ \text { thiazole } & \text { thiazole } \\ \text { thiazole } & \text { thiazoline } \\ \text { thiazoline } & \text { thiazoline } \\ \text { thiazole } & \text { thiazoline } \\ \text { thiazole } & \text { thiazoline } \\ \text { thiazoline } & \text { thiazoline } \\ \text { thiazoline } & \text { thiazoline }\end{array}$

Scheme 5. Marine-derived 1,3-oxazole-containing monocyclic heptapeptides (82-96).

\subsubsection{Octapeptides}

Sanguinamide B (97) (Scheme 6) was a modified macrocyclic octapeptide containing five L-amino acids, two thiazoles and one oxazole from the nudibranch Hexabranchus sanguineus [69]. The first total synthesis of $\mathbf{9 7}$ was achieved by Singh and coworkers in 2012 and determined its configuration as trans [70]. Myriastramides A-C (98-100) were new modified cyclic peptides purified from the Philippines marine sponge Myriastra clavosa [71]. Haliclonamides A-E (101-105), produced by the marine sponge Haliclona sp., displayed an antifouling effect on the blue mussel Mytilus edulis galloprovincialis [72,73]. Chemical analysis of the marine sponge T. swinhoei, collected on an isolated reef of the Solomon Islands, yielded two anti-inflammatory octapeptides, perthamides J (106) and K (107) [74]. Ascidiacyclamide (108), formed by the cyclization of [Ile-Oxz- $D-$ Val-Tz- $]_{2}$, was purified from an unidentified species of ascidian grown on Rodda Reef (Australia) and contains four five-membered heterocycles, where the number and position of oxazoline residues were shown to affect its cytotoxicity [75]. Prepatellamide A (109), prepatellamide B formate (110) and patellamides A-G (111-117) were successively obtained from the ascidian Lissoclinum patella, of which compounds 109, 113, 114 and 111 exhibited modest cytotoxicity against P388 murine leukemia cell lines [76-84]. Gene knockout studies indicated that the Pat cluster (pat A-G) was responsible for patellamide biosynthesis [85]. One anti-MRSA thiazolyl peptide, kocurin (118), produced by the marine-derived bacterium Kocuria palustris, collected in Florida Keys (Florida, FL, USA), structurally consists of L-Tyr, L-Pro, L-Ala, L-Asp, L-Phe, L-Cya, L-Pro ( $\times 2)$, L-Ala and L-Cys [86]. Biosynthetically, the formation of oxazole and thiazoline rings of $\mathbf{1 1 8}$ were catalyzed by KocE, and its serine residues were dehydrated by $\mathrm{KocB}$ and $\mathrm{KocC}$, followed by the Aza-Diels-Alder reaction catalyzed by KocD, resulting in a generation of a 29-membered cycle [87]. 


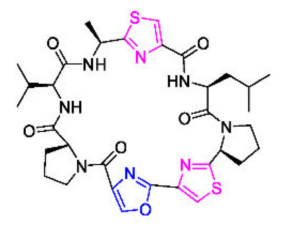

97

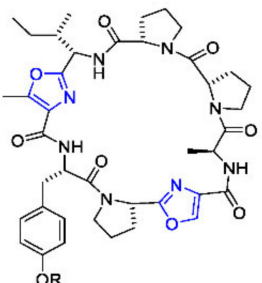

$98 \mathrm{R}=3 \mathrm{2}$ $99 \mathrm{R}=$ Cl $_{\mathrm{C}}$

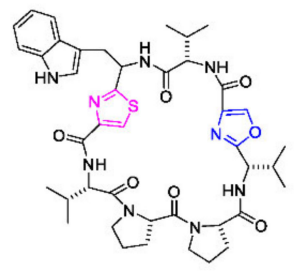

100

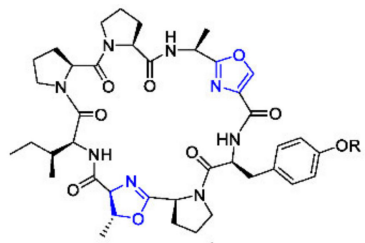

$101 \mathrm{R}=$ 等

$102 \mathrm{R}=\mathrm{H}$

$103 \mathrm{R}=$ 占H

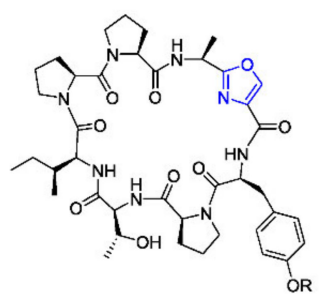

$104 \mathrm{R}=\mathrm{H}$

$105 \mathrm{R}=$ 红

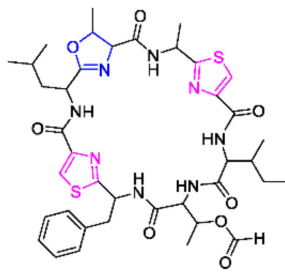

110

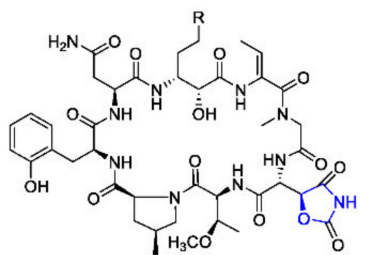

$106 \mathrm{R}=$ 年

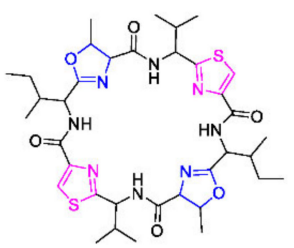

108

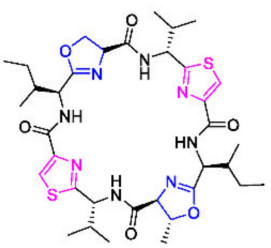

109

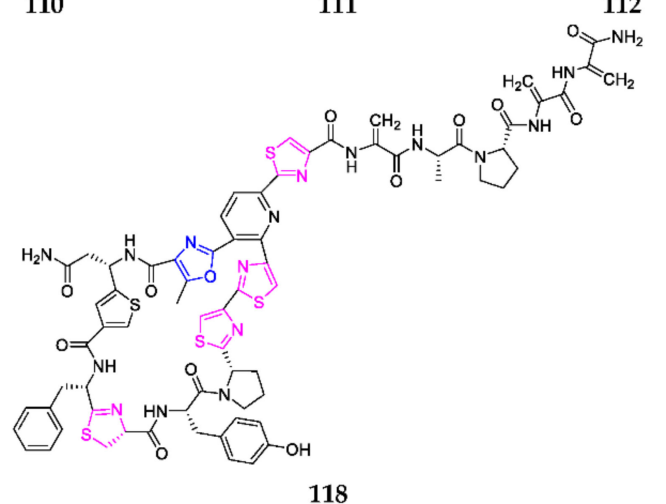

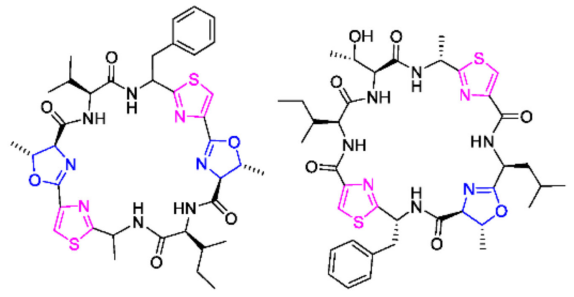

112

Scheme 6. Marine-derived 1,3-oxazole-containing monocyclic octapeptides (97-118).

\subsubsection{Other Monocyclic Peptides}

In addition to mechercharmycin B (28), one monocyclic nonapeptide, mechercharmycin A (119) (Scheme 7), was purified from the marine strain Thermoactinomyces sp. YM3-251 and shown to have excellent cytotoxicity toward A549 and Jurkat cells, with $\mathrm{IC}_{50}$ values of 40 and $46 \mathrm{nM}$, respectively [29]. Urukthapelstatin A (120) was detected in the fermentation broth of the marine strain Mechercharimyces asporophorigenens YM11-542, from Urukthapel Island (Palau), and displayed a broad spectrum of potential cytotoxicities [88]. By the macrocyclization of one macrothiolactone, and the azole formatted by the Aza-Wittig ring contraction, chemical synthesis of compound $\mathbf{1 2 0}$ was first achieved by Schwenk and coworkers [89]. Interestingly, the SAR study showed that the phenyl ring attached to the eastern oxazole, and the rigid lipophilic tripeptide section definitely affected its cytotoxicity [90]. One new thiopeptide TP-1161 (121) was isolated from one marine Nocardiopsis sp. and its biosynthetic gene cluster (BGC) was confirmed by targeted gene inactivation [91]. This substance exhibited no inhibitory effect on Gram-negative bacteria, but excellent 
antimicrobial activity against a panel of Gram-positive clinical isolates [92]. Wewakazole (122) and wewakazole B (123) were novel cyclic dodecapeptides produced by cyanobacteria Lyngbya majuscule from Papua New Guinea, and Moorea producens collected in the red sea, respectively [93]. Bioassay results suggested that compound 122 was active against nonsmall cell lung cancer $\mathrm{H}-460$ cells $\left(\mathrm{IC}_{50} 10.1 \mu \mathrm{M}\right)$ and that $\mathbf{1 2 3}$ had a stronger cytotoxicity against $\mathrm{H} 460$ cells $\left(\mathrm{IC}_{50} 1.0 \mu \mathrm{M}\right)$ and MCF7 breast cancer cells $\left(\mathrm{IC}_{50} 0.58 \mu \mathrm{M}\right)$. The first total synthesis of $\mathbf{1 2 3}$ was achieved through the careful choice of amino acid-protecting groups and the construction of three different substituted oxazoles [94].

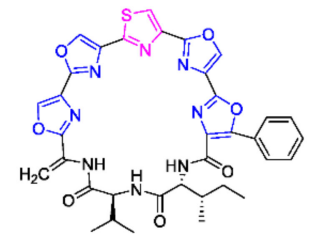

119

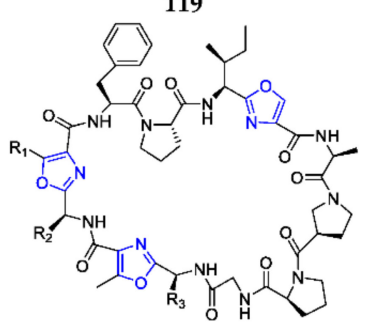

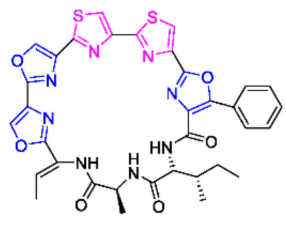

120

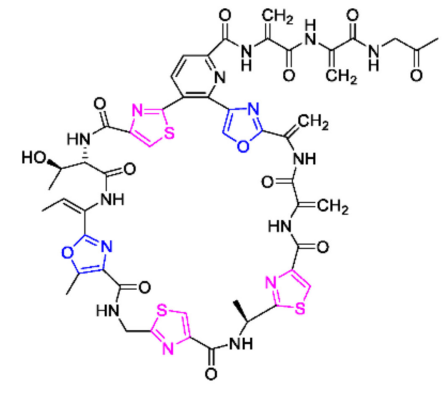

121

Scheme 7. Marine-derived 1,3-oxazole-containing other monocyclic peptides (119-123).

\subsection{Bicyclic Peptides}

Chemical analysis of the ascidian Diazona angulate led to discovery of five new peptides with two 12-membered macrocycles connected by a quaternary carbon stereo center, substituted by triaryl groups in furan indole nuclei, diazonamides A-E (124-128) (Scheme 8). In particular, compound $\mathbf{1 2 4}$ displayed an extraordinary antitumor effect on a HCT-116 human colon carcinoma and B-16 murine melanoma cancer cell lines, with $\mathrm{IC}_{50}$ values less than $15 \mathrm{ng} / \mathrm{mL}[95,96]$, and was chemically synthesized by using the Witkop photocyclization reaction for the first time [97]. Lissoclinum patella is the prolific producer of the new sulfur-containing bicyclic peptides ulithiacyclamide (129), ulithiacyclamide B (130), ulithiacyclamide F (131) and ulithiacyclamide G (132) $[67,76,98]$. Biological evaluation showed that compounds $\mathbf{1 2 9}$ and $\mathbf{1 3 0}$ excellently inhibited the growth of the KB cell line with an $\mathrm{IC}_{50}$ of 35 and $17 \mathrm{ng} / \mathrm{mL}$, respectively.
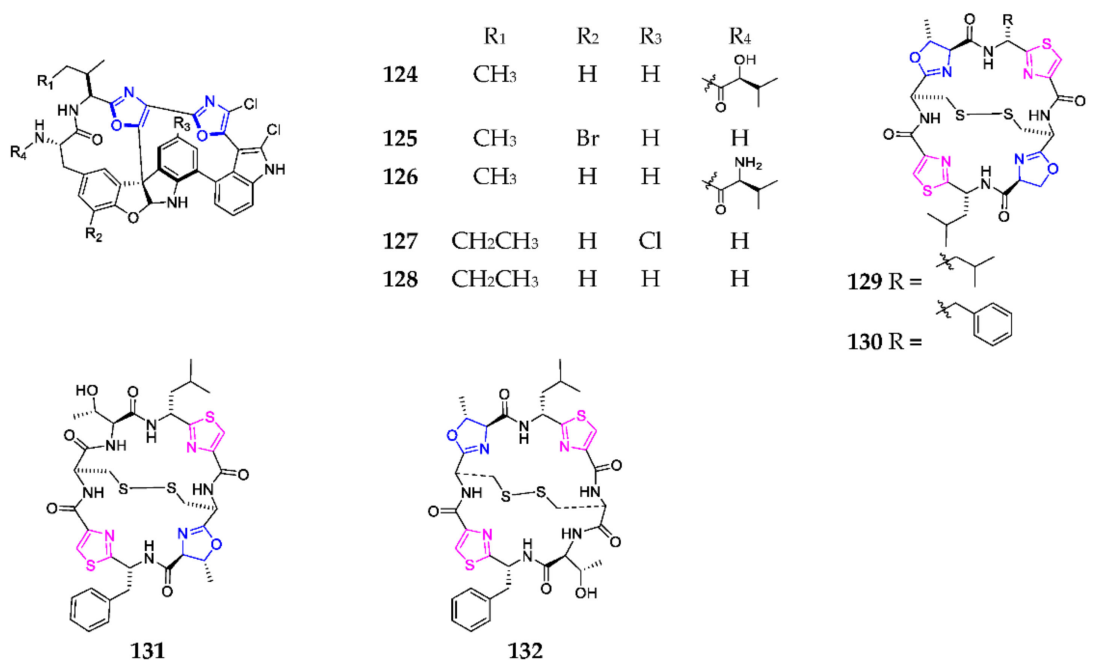

132

Scheme 8. Marine-derived 1,3-oxazole-containing bicyclic peptides (124-132). 


\subsection{Depsipeptides}

Taumycin A (133) was obtained from the Madagascan sponge Fascaplysinopsis sp. and found to inhibit the growth of the human UT-7 leukemic cell line at $1 \mu \mathrm{M}$ [99]. Total synthesis study indicated that macrocyclization initiated by the thermal rearrangement of $\beta$-keto tert-butyl ester yielded $21 \%$ of $\mathbf{1 3 3}$ (Scheme 9 ) and determined the configuration of C-9 as $S$ [100]. Four cyclic depsipeptides, discokiolides A-D (134-137), were characterized from the marine sponge Discodermia kiiensis and exhibited a broad spectrum of cytotoxic activities against P388, P388/ADM, B16-BL6, Lewis, Lu-99, HT-29 and CCD-19Lu with $\mathrm{IC}_{50}$ values ranged from 0.5 to $7.2 \mu \mathrm{g} / \mathrm{mL}$ [101].
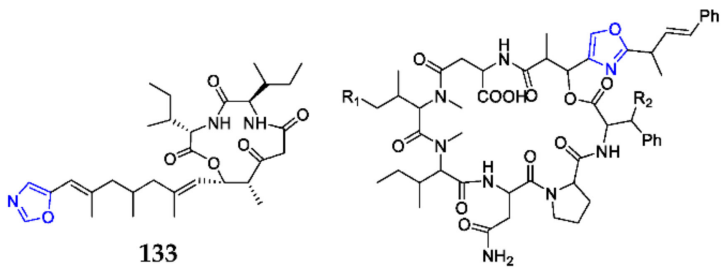

$\begin{array}{ccc} & \mathrm{R}_{1} & \mathrm{R}_{2} \\ 134 & \mathrm{H} & \mathrm{OCH}_{3} \\ 135 & \mathrm{CH}_{3} & \mathrm{OCH}_{3}\left(\triangle^{8}\right) \\ 136 & \mathrm{CH}_{3} & \mathrm{H} \\ 137 & \mathrm{CH}_{3} & \mathrm{OCH}_{3}\left(\triangle^{7}\right)\end{array}$

Scheme 9. Marine-derived 1,3-oxazole-containing depsipeptides (133-137).

\section{Macrolides}

\subsection{Endocyclic Oxazoles}

\subsubsection{Mono-Oxazole Macrolides}

Until 2020, marine sponges were the only sources of macrolides containing a monooxazole motif. Two cytotoxic isomers, phorboxazoles A (138) (Scheme 10) and B (139), as well as the precursor (140) were detected in the Indian Ocean marine sponge Phorbas sp. [102,103]. Leiodolides A (141) and B (142) were the first members of a new class of mixed polyketide-nonribosomal peptide synthetase from the deep-water marine sponge Leiodermatium. They structurally possess a 19-membered ring and several unique functional groups, including a bromine substituent and an $\alpha$-hydroxy- $\alpha$-methyl carboxylic acid sidechain terminus. These substances had obvious cytotoxic effects against human colon cancer HCT-116 with $\mathrm{IC}_{50}$ values of 2.5 and $5.6 \mu \mathrm{M}$, respectively [104]. Chemical investigation of the Madagascan sponge Fascaplysinopsis sp. afforded three macrolides with bis-epoxide motif salarins 143-145, which showed pronounced inhibitory on human leukemia cell lines UT-7 [105,106]. Theonezolides A-C (146-148) from the Okinawan Theonella sp. were novel oxazole-containing macrolides that compose of two main fatty acid chains, including a 37-membered macrolide ring with long side chains connected by amide bonds. They exhibited cytotoxicity on a murine lymphoma L1210 and human epidermoid carcinoma KB cells and induced a platelet morphology change and aggregation in rabbits [107-109].

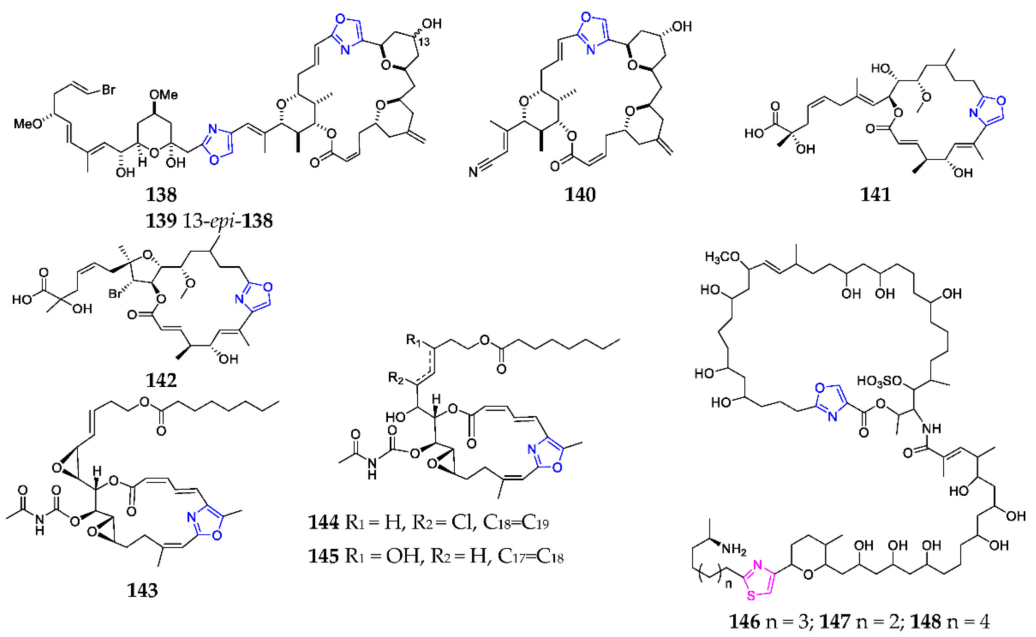

Scheme 10. Marine-derived endocyclic mono-oxazole macrolides (138-148). 


\subsubsection{Dioxazole Macrolides}

Three 25-membered macrolides consisted of two consecutive oxazole rings, kabiramide I (149) (Scheme 11), halishigamide B (150) and mycalolide D (151), were respectively isolated from the Thai sponge Pachastrissa nux, the Okinawan Halichondria sp., and the stony coral Tubastrea faulkneri, of which compound $\mathbf{1 5 0}$ had a weak cytotoxicity against L1210 and a modest antifungal effect on T. mentagrophytes, while $\mathbf{1 5 1}$ showed a modest general cytotoxicity with average $\mathrm{LC}_{50}$ values of $0.6 \mu \mathrm{M}$ against the NCI's 60-human tumor cell line [110-112].

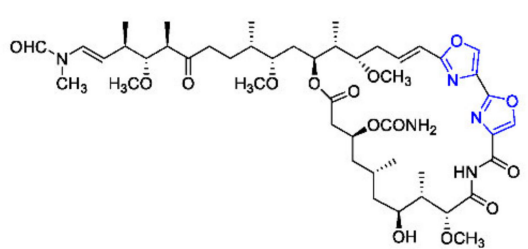

149

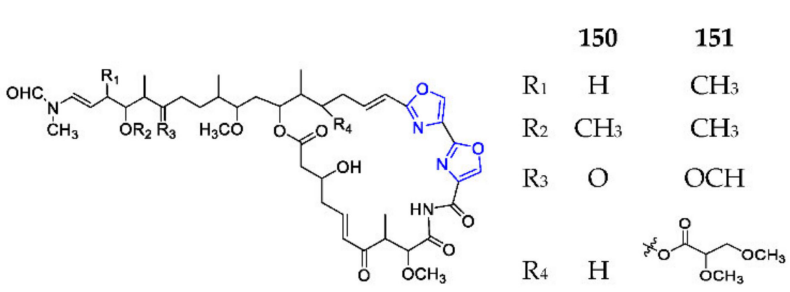

Scheme 11. Marine-derived endocyclic dioxazole macrolides (149-151).

\subsubsection{Trioxazole Macrolides}

Trioxazole macrolides with extended aliphatic tails are an unprecedented class of natural products and have not been found in terrestrial organisms before [113]. Ulapualides A-E (152-156) (Scheme 12) were extracted from the nudibranch Hexabranchus sanguineus, and compounds 152 and 153 displayed an inhibitory effect on the L1210 leukemia cell with $\mathrm{IC}_{50}$ values ranged from 0.01 to $0.03 \mu \mathrm{g} / \mathrm{mL}$ [114]. Miuramides A (157) and B (158) of the Mycale sp. sponge collected from Miura Peninsula were shown to possess potent cytotoxicities against $3 \mathrm{Y} 1$ cells in the $\mathrm{nM}$ range [115].

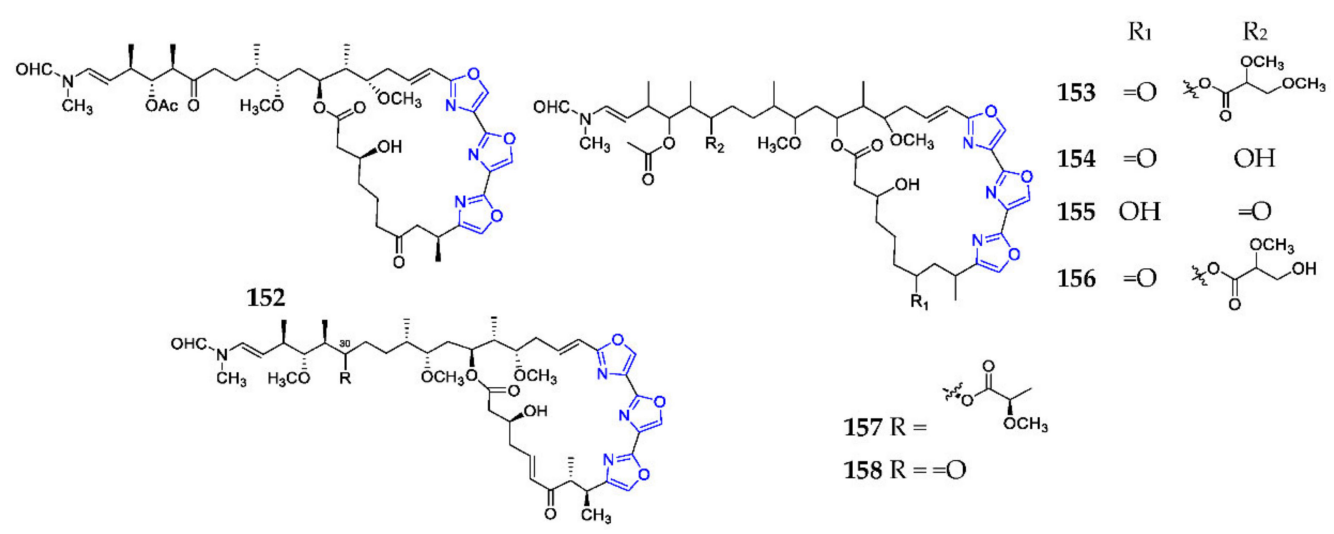

Scheme 12. Marine-derived endocyclic trioxazole macrolides (152-158).

Mycalolides A-C (159-161) (Scheme 13) and their derivatives (162-165, 176, 177, 179) were obtained from a marine sponge of the genus Mycale, except mycalolide E (166) from the coral Tubastrea faulkneri, of which $\mathbf{1 7 6}$ and $\mathbf{1 7 7}$ possessed one sulfur atom connected to the glutathionyl group (i-Glu-Cys-Gly) at C-5 [116]. Bioassay revealed that these substances exhibited excellent cytotoxicities [117]. Phytochemical analysis of sponges Halichondria sp., Jaspis sp., Chondrosia corticata and nudibranch Hexabranchus sanguineus resulted in the discovery of thirteen halichondramides (166-181, 183, 184), which had significant antifungal and cytotoxic effects [111,118]. Kabiramides (180-182, 185-192) were discovered in the Hexabranchus egg masses and the sponge Pachastrissa nux, and displayed extraordinary cytotoxicities, and antiplasmodial and antifungal activities [119]. 

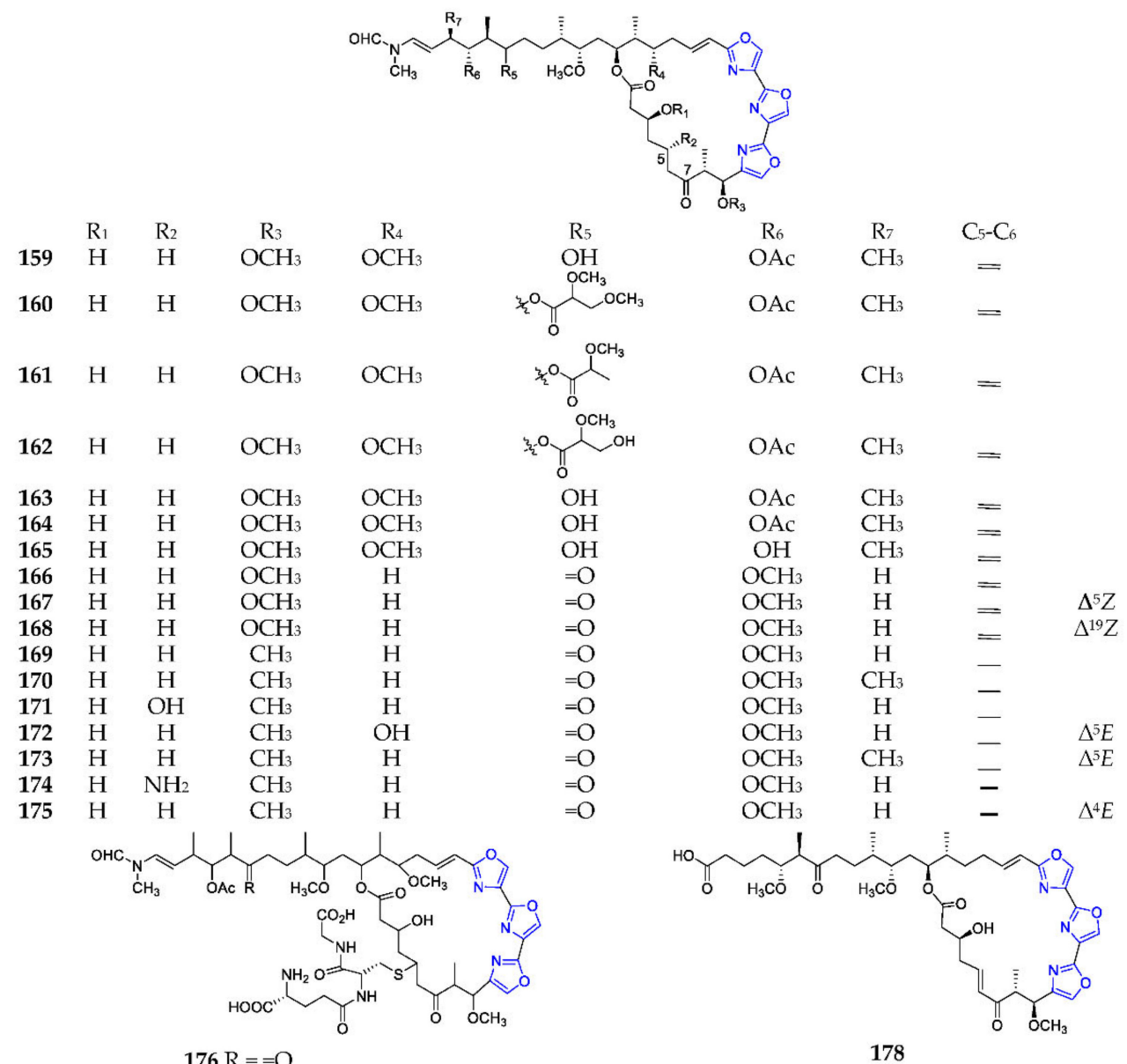

$176 \mathrm{R}==\mathrm{O}$

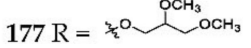

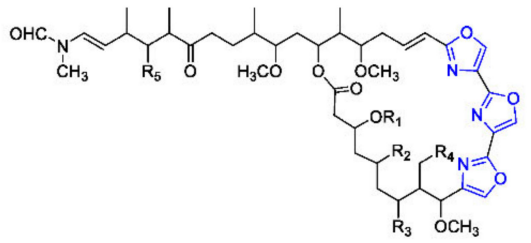

$\begin{array}{lc} & \mathrm{R} 1 \\ \mathbf{1 7 9} & \mathrm{OH} \\ \mathbf{1 8 0} & \mathrm{CONH}_{2} \\ \mathbf{1 8 1} & \mathrm{CONH}_{2} \\ \mathbf{1 8 2} & \mathrm{COCH}_{3}\end{array}$

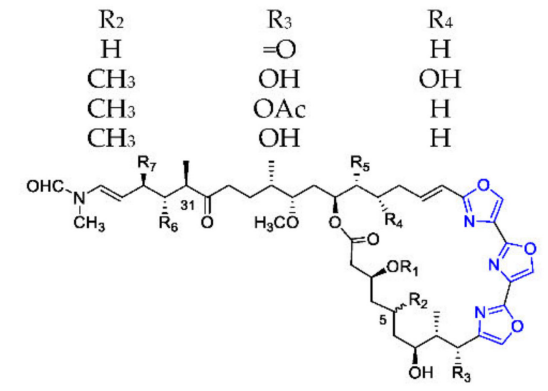

\begin{tabular}{|c|c|c|c|c|c|c|c|c|}
\hline & $\mathrm{R}_{1}$ & $\mathrm{R}_{2}$ & $\mathrm{R}_{3}$ & $\mathrm{R}_{4}$ & $\mathrm{R}_{5}$ & $R_{6}$ & $\mathrm{R}_{7}$ & $\mathrm{C}_{31}-\mathrm{C}_{32}$ \\
\hline 183 & $\mathrm{H}$ & $\mathrm{H}$ & $\mathrm{CH}_{3}$ & $\mathrm{H}$ & $\mathrm{CH}_{3}$ & $\mathrm{OCH}_{3}$ & $\mathrm{H}$ & - \\
\hline 184 & $\mathrm{CONH}_{2}$ & $\mathrm{CH}_{3}$ & $\mathrm{H}$ & $\mathrm{OH}$ & $\mathrm{CH}_{3}$ & $\mathrm{OCH}_{3}$ & $\mathrm{CH}_{3}$ & - \\
\hline 185 & $\mathrm{CONH}_{2}$, & $\mathrm{CH}_{3}$ & $\mathrm{CH}_{3}$ & $\mathrm{H}$ & $\mathrm{CH}_{3}$ & $\mathrm{OCH}_{3}$ & $\mathrm{CH}_{3}$ & - \\
\hline 186 & $\mathrm{CONH}_{2}$ & $\mathrm{CH}_{3}$ & $\mathrm{CH}_{3}$ & $\mathrm{CH}_{3}$ & $\mathrm{CH}_{3}$ & $\mathrm{OCH}_{3}$ & $\mathrm{CH}_{3}$ & - \\
\hline 187 & $\mathrm{H}$ & $\mathrm{CH}_{3}$ & $\mathrm{CH}_{3}$ & $\mathrm{CH}_{3}$ & $\mathrm{CH}_{3}$ & $\mathrm{OCH}_{3}$ & $\mathrm{CH}_{3}$ & - \\
\hline 188 & $\mathrm{H}$ & $\mathrm{CH}_{3}$ & $\mathrm{CH}_{3}$ & $\mathrm{H}$ & $\mathrm{H}$ & $\mathrm{OCH}_{3}$ & $\mathrm{CH}_{3}$ & - \\
\hline 189 & $\mathrm{CONH}_{2}$ & $\mathrm{CH}_{3}$ & $\mathrm{CH}_{3}$ & $\mathrm{H}$ & $\mathrm{CH}_{3}$ & $\mathrm{H}$ & $\mathrm{CH}_{3}$ & $=$ \\
\hline 190 & $\mathrm{CONH}_{2}$ & $\mathrm{CH}_{3}$ & $\mathrm{CH}_{3}$ & $\mathrm{CH}_{3}$ & $\mathrm{CH}_{3}$ & $\mathrm{H}$ & $\mathrm{CH}_{3}$ & $=$ \\
\hline 191 & $\mathrm{H}$ & $\mathrm{CH}_{3}$ & $\mathrm{CH}_{3}$ & $\mathrm{CH}_{3}$ & $\mathrm{CH}_{3}$ & $\mathrm{H}$ & $\mathrm{CH}_{3}$ & $=$ \\
\hline 1 & $\mathrm{H}$ & $\mathrm{CH}_{3}$ & $\mathrm{CH}_{3}$ & $\mathrm{H}$ & $\mathrm{CH}_{3}$ & $\mathrm{H}$ & $\mathrm{CH}_{3}$ & $=$ \\
\hline
\end{tabular}

Scheme 13. Marine-derived endocyclic trioxazole macrolides (159-192) (Cont.). 


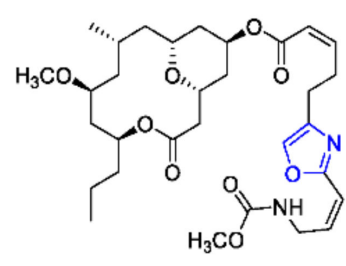

193

\subsection{Exocyclic Oxazoles}

Neopeltolide (193) (Scheme 14) was one of the new exocyclic oxazole-containing macrolides from a deep-water sponge of the family Neopeltidae, and was found to have potential antifungal effects against $C$. albicans and inhibitory activities against A-549, NCIADR-RES and P388 cell lines with $\mathrm{IC}_{50}$ values of $1.2,5.1$ and $0.56 \mathrm{nM}$, respectively [120]. SAR analysis revealed that the substitution of the side chain and the stereochemistry of the macrolide carbon, especially C-11 and C-13, is vital for the overall biological property [121]. One doubly O-bridged 18-membered macrolide, leucascandrolide A (194), was detected in a calcareous sponge of a new genus Leucuscundra caveoluta from the Coral Sea [122]. Pharmacological study indicated that this metabolite was a novel inhibitor of cytochrome $b c_{1}$ [123]. Enigmazoles 195-197, from the sponge Cinachyrella enigmatica, were a new structural family of marine phosphomacrolides with an 18-membered macrocyclic ring, which consists of an embedded 2,6-cis-substituted tetrahydropyran ring, a 2,4-disubstituted oxazole ring in the side chain, and a phosphate group. These substances can inhibit cells with either a wild-type or mutant c-Kit. However, their actual cellular targets are still unknown [124]. The first chemical synthesis of 195 and 196 required a tandem olefin cross-metathesis/intramolecular oxa-Michael addition reaction [125].
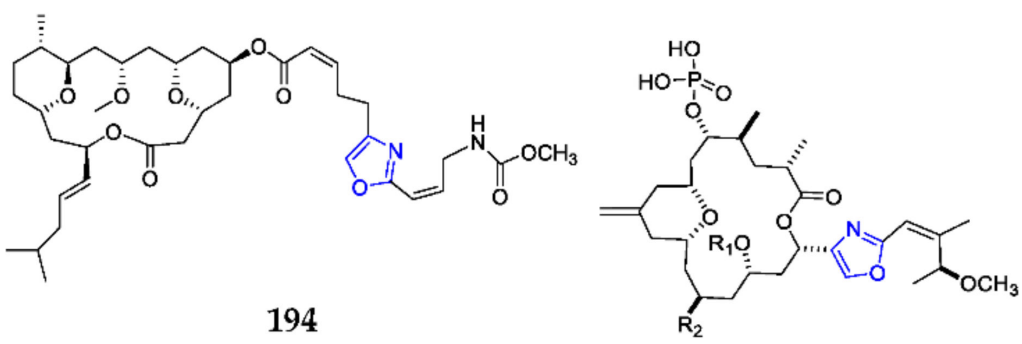

$\begin{array}{ccc}195 & \mathrm{H} & \mathrm{H} \\ 196 & \mathrm{CH} & \mathrm{H} \\ 197 & \mathrm{CH}_{3} & \mathrm{OH}\end{array}$

\section{Polyketides}

\subsection{Mono-Oxazole Polyketides}

Calyculins (198-216) (Scheme 15) were novel polyketides containing a mono-oxazole and a phosphate group from the marine sponges Discodermia calyx, Lamellomorpha strongylat, Luffariella geometrica, Myriastra clavosa and Theonella swinhoei. These natural products exhibited extensive biological properties including cytotoxicity, antifungal activity and an inhibitory effect on protein phosphatases [126-131]. By OSMAC (one strain many compounds) strategy, inthomycin B (217) was produced by the marine sediment-derived Streptomyces YB104 and was found to have anti-oomycete, cytotoxic and herbicidal activities [132]. One concise method to synthesize $\mathbf{2 1 7}$ was developed by Webb and coworkers through the Stille coupling of a stannyl-diene with an oxazole vinyl iodide unit and a Kiyooka ketene acetal/amino acid-derived oxazaborolidine procedure as its cornerstones [133]. And the gene cluster $(\mathrm{itm})$ responsible for biosynthesis of 217 was identified as a $95.3 \mathrm{~kb}$ trans-AT type I PKS system, of which the gene Itm 15 is a cyclodehydrase to catalyze the formation of oxazole ring [132].

\subsection{Dioxazole Polyketides}

Four analogs of the trioxazole macrolide 169 linked with a methyl ester and a primary amide group, secohalichondramide (218) (Scheme 16), halishigamides C (219) and D (220), and kabiramide $\mathrm{H}$ (221), were isolated from marine sponges, including Chondrosia corticate, Halichondria sp. and Pachastrissa nux [110,111,134]. Metabolites 219 and 220 showed weak cytotoxicity against L1210 and KB cell lines and a modest antifungal activity against T. mentagrophytes [111]. By extensive chromatographic techniques, eight hennoxazoles (222-229) were isolated from the sponge Polyfibrospongia sp., of which $\mathbf{2 2 2}$ had peripheral analgesic activity equivalent to the positive control of indomethacin, and 228 exhibited the greatest cytotoxicity toward $\mathrm{L} 1210$ with an $\mathrm{IC}_{50}$ value of $2 \mu \mathrm{g} / \mathrm{mL}[135,136]$. Antibiotic 
B-90063 (230) was a novel endothelin-converting enzyme (ECE) inhibitor from the marine strain Blastobacter sp. SANK 71894, collected off the coast of Ojika Peninsula [137]. Bengazoles 231-236 were antifungal agents obtained from the marine sponge Pachastrissa sp., collected at Musha Archipelago (Djibouti) [138]. An uncommon oxazole, bengazole A (237) from the sponge Jaspis sp., displayed remarkable ergosterol-dependent antifungal activity against C. albicans, which is equivalent to amphotericin B [139].
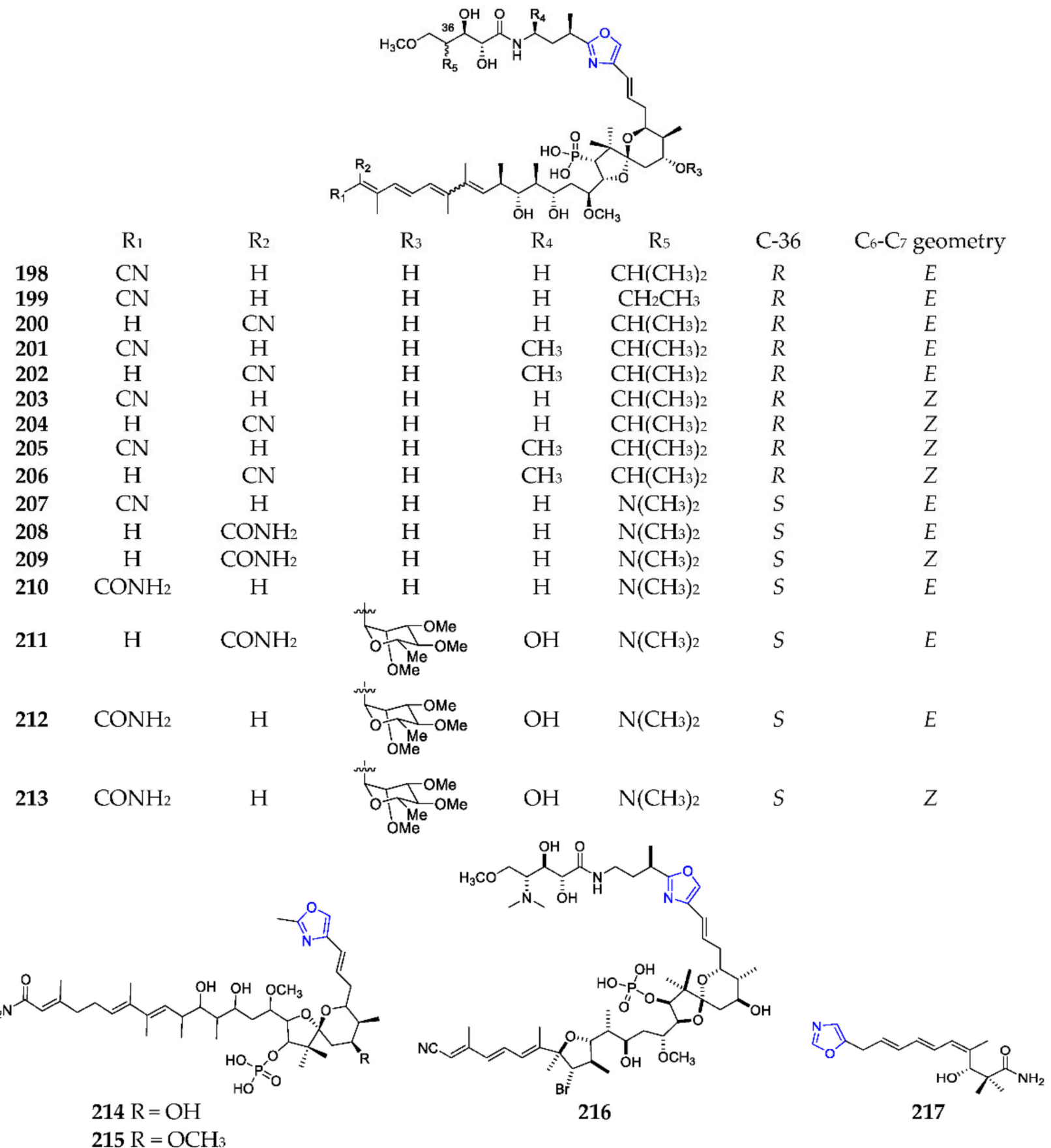

Scheme 15. Marine-derived mono-oxazole polyketides (198-217). 


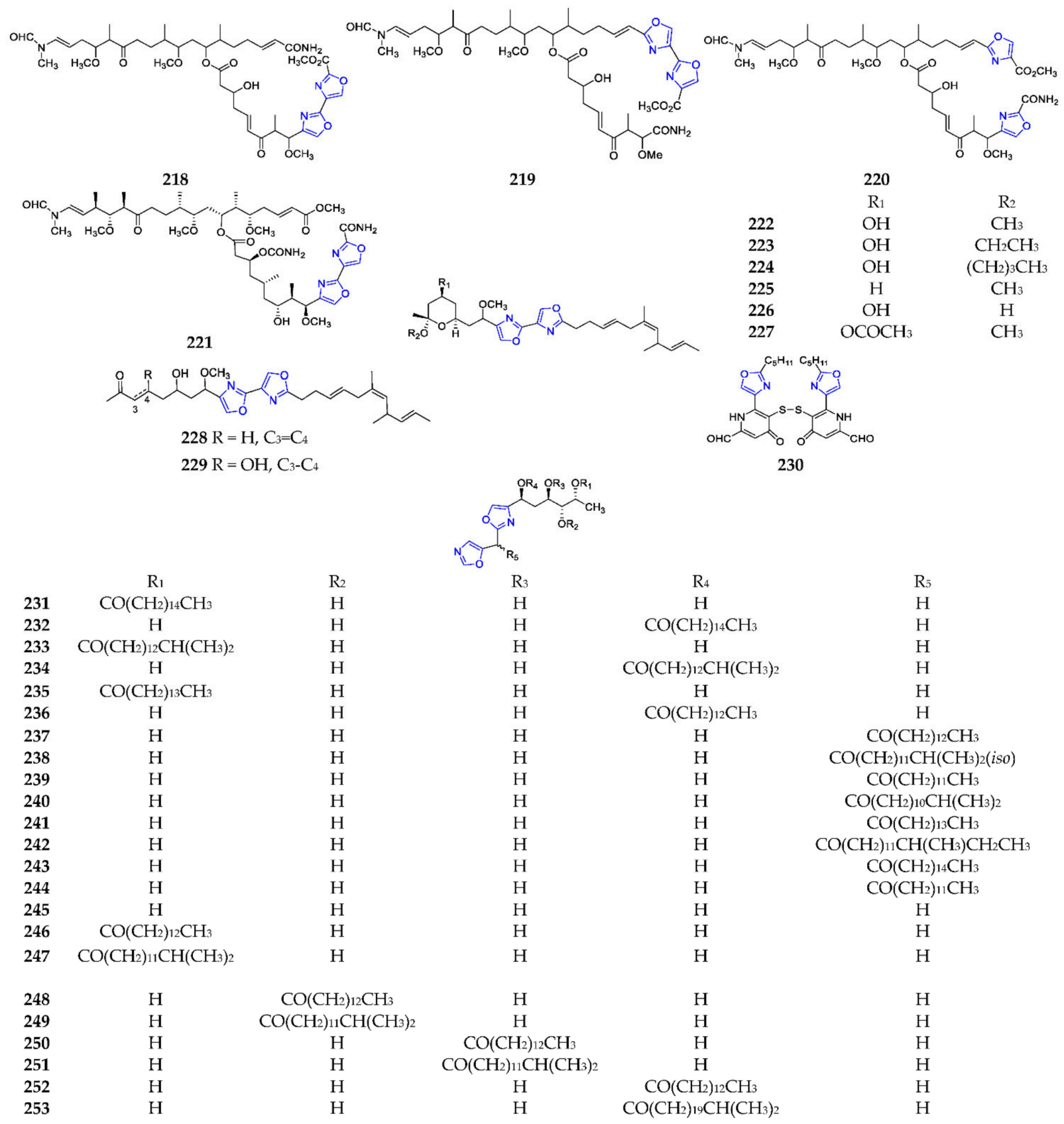

Scheme 16. Marine-derived dioxazole polyketides (218-253).

\section{Benzoxazoles}

Benzoxazole-containing compounds are one important class of natural products with a potential application in pharmaceutical and agrochemical fields $[140,141]$. Ten sesquiterpenoid benzoxazoles (254-263) (Scheme 17) have been successively purified from marine sponges since 1995, including the Okinawan sponge of the family Spongiidae, the Smenospongia sp., the Hyrtios sp., and the Dactylospongia sp. [142-145]. A novel approach to totally synthesize these substances was developed through the cyclic closure of the $\mathrm{N}$-(2-hydroxyphenyl)-formamide or -acetamide groups to obtain the desired dihydroxybenzoxazole substructure [146]. Chemical study of a halophilic strain Nocardiopsis lucentensis DSM 44048 yielded seven new benzoxazoles, nocarbenzoxazoles A-G (264-270), in which 270 had selective activity against HepG2 and HeLa cell lines with a $\mathrm{IC}_{50}$ of 3 and $1 \mu \mathrm{M}$, respectively [147]. Recently, a simple route to the synthesis of 269 and 270 was achieved by microwave-assisted construction of a benzoxazole skeleton [148]. One 6-methoxy-2(3H)- 
benzoxazolinone, coixol (271), was detected in the DCM-MeOH extract of the marine sponge Oceanapia sp., collected off Mandapam coast (India), and had extensive bioactivities, including an inhibitory effect on brine shrimp, anti-inflammation and anti-diabetes [149]. Bioassay-guided fractionation of an extract from the sea plum Pseudopterogorgia elisabethae led to the isolation of homopseudopteroxazole (272), pseudopteroxazole (273), seco-pseudopteroxazole (274) and ileabethoxazole (275) $[150,151]$. Oxazocurcuphenol (276) was isolated and characterized from the coral P. rigida, collected at Lighthouse Point on the Eleuthera island (Nassau, Bahamas) [152]. Biological tests suggested that 272 and 273-275 strongly inhibited the growth of Mycobacterium tuberculosis $\mathrm{H}_{37} \mathrm{R} 0 \mathrm{v}$ at $12.5 \mu \mathrm{g} / \mathrm{mL}$. Compounds 272 and 273 were chemically synthesized by a rapid one-pot method [153], and the total synthesis of 275 was accomplished using a new enantioselective approach [154].

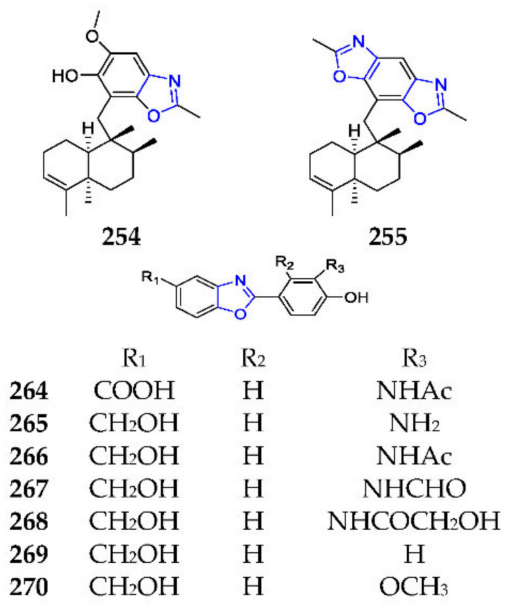

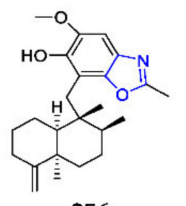

256

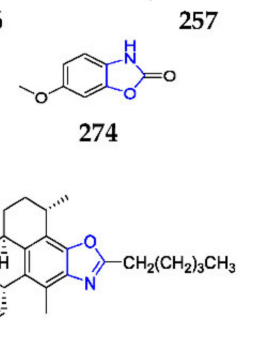

272

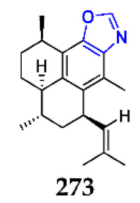

273

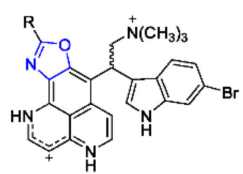

$279 \mathrm{R}=$ 年 $\mathrm{SO}_{3} \cdot$

$280 \mathrm{R}=\mathrm{O}^{\mathrm{N}}$

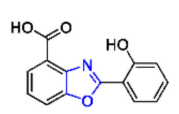

281
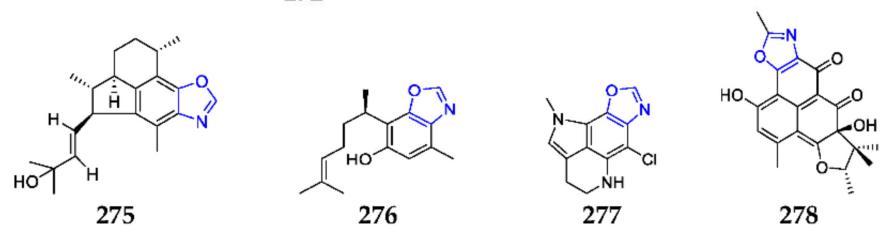

274

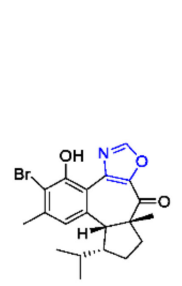

282

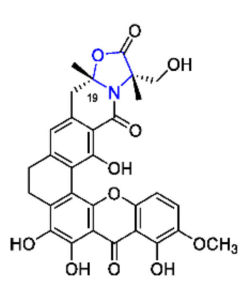

283
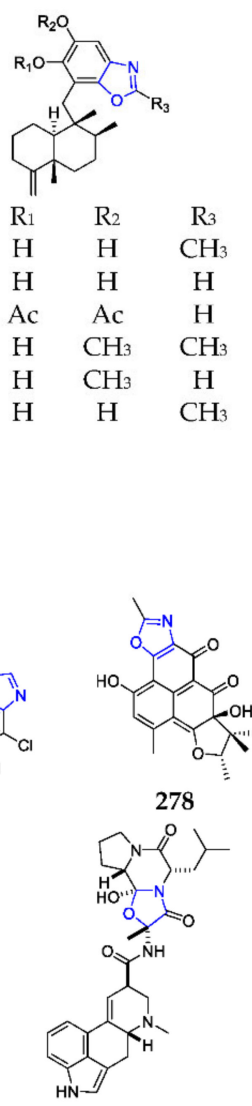

285

Scheme 17. Marine-derived benzoxazoles (254-285).

To the best of our knowledge, citharoxazole (277) was the first chlorinated oxazolecontaining pyrrolo[4,3,2-de]quinoline from the Mediterranean deep-sea sponge Latrunculia (Biannulata) citharistae [155]. Culture of the marine fungus Penicillium sp. from a marine sediment resulted in the production of herqueioxazole (278), which was the first oxazolecontaining phenalenone [156]. The marine sponge Suberites sp. was the unique source to produce nakijinamines $\mathrm{C}(\mathbf{2 7 9})$ and $\mathrm{E}(\mathbf{2 8 0})$ with a $1 H$-oxazolo[40,50:4,5]benzo[1,2,3-de] [1,6] naphthyridine ring system [157]. One new benzoxazole caboxamycin (281), from the deep-sea strain Streptomyces sp. NTK 937, was found to strongly inhibited phosphodiesterases [158]. Lately, one facile method for synthesis of this antibiotic has been developed via debenzylation and demethylation, under eco-friendly and simple reaction conditions [159], and one regulatory and nine structural genes involved in its biosynthesis have been confirmed through genetic manipulation [160]. Hamigeran M (282) was the first non-benzo-fused oxazole-containing terpenoid from the New Zealand marine sponge 
Hamigera tarangaensis, and exhibited the high efficacy against the HL-60 promyelocytic leukemia cell line with a mean $\mathrm{IC}_{50}$ value of $6.9 \pm 0.4 \mu \mathrm{M}$ [161]. Two novel anti-MRSA xanthones, citreamicins $\theta \mathrm{A}(\mathbf{2 8 3})$ and $\theta \mathrm{B}(\mathbf{2 8 4})$, were separated from one marine-derived strain of Streptomyces caelestis [162]. Ergosinine (285) was one ergot alkaloid possessing an oxazole ring from the sea slug Pleurobranchus forskalii, collected off Ishigaki Island (Ishigaki, Japan) and found to have an anti-adrenergic effect [163].

\section{Conclusions}

In recent decades, a tremendous number of 1,3-oxazole-containing alkaloids have been isolated and characterized from marine organisms, including marine invertebrates, nematodes, insects, vertebrates cyanobacteria, bacteria, and fungi. These substances possess unique chemical structures and exhibit a wide variety of biological properties. Many important marine-derived 1,3-oxazoles have great potential for the development of leading compounds in the search for new drugs and medicines. For example, mechercharmycin A (119) is a promising antitumor remedy, and (19Z)-halichondramide (168), neohalichondramide (175), and calyculin A-D (190, 200-202) have the potential to treat human leukemia cell line. Besides, plenty of these substances are potential antimicrobial agents, such as kocurin (118), TP-1161 (121) homopseudopteroxazole (272), and so on. However, (1) how to reduce cytotoxicity, (2) how to improve drug stability, and (3) how to make the drug work quickly and effectively in vivo still needs to be studied in further depth.

In recent years, however, the number of new 1,3-oxazole derivatives from marine organisms has greatly decreased, since almost all accessible macroorganisms have been collected and chemically analyzed. Simultaneously, marine microorganisms are shown to be one prolific and unexploited source of bioactive natural products, owing to their species richness and abundant secondary metabolite BGCs, especially symbiotic microbes of marine sponges, seaweeds, mangroves and tunicates [164-167]. In order to discover novel marine microbe-derived 1,3-oxazoles for new drug discovery, more efforts should be made to conduct strain isolation and chemical study using a combination of classical methods (e.g., cultivation and fermentation, bioassay-guided fractionation, structure elucidation) and advanced analytical techniques (e.g., metabolomics, higher-field NMR instruments, probe technology), genome mining and engineering and microbial cultivating systems (e.g., OSMAC approach) [168].

Supplementary Materials: The following are available online at https:/ /www.mdpi.com/article/ 10.3390/ph14121274/s1. Detailed information for 1,3-oxazole-containing alkaloids (1-285) from marine organisms is available in Table S1.

Author Contributions: Conceptualization, H.Z.; Funding acquisition, H.W. and H.Z.; Project administration, H.Z.; Supervision, H.Z.; Writing—original draft, J.C., S.L., J.L.; Writing—review \& editing, Y.Y. and H.Z. All authors have read and agreed to the published version of the manuscript.

Funding: Financial supports from the National Key R\&D Program of China (2018YFC0311004), the National Natural Science Foundation of China (41776139) and the Fundamental Research Fund for the Provincial Universities of Zhejiang (China) (RF-C2019002) were greatly appreciated.

Institutional Review Board Statement: Not applicable.

Informed Consent Statement: Not applicable.

Data Availability Statement: Detail information for all 1,3-oxazole-containing alkaloids described in this work is available at Table S1.

Conflicts of Interest: The authors declare no conflict of interest. 


\begin{tabular}{ll}
\multicolumn{2}{l}{ Abbreviations } \\
ADP & Adenosine diphosphate \\
Ala & Alanine \\
Anti-MRSA & Anti-methicillin-resistant Staphylococcus aureus \\
Asp & Aspartate \\
ATP & Adenosine triphospha \\
BGC & Biosynthetic gene cluster \\
Cys & Cysteine \\
DCM & Dichloromethane \\
DPPH & 1,1-Diphenyl-2-picrylhydrazyl \\
ECE & Endothelin-converting enzyme \\
ED 50 & Median effective dose \\
FMN & Flavin mononucleotide \\
FMNH 2 & Flavin mononucleotide reduced \\
Glu & Glutamic acid \\
Gly & Glycine \\
IC 50 & Half maximal inhibitory concentration \\
Ile & Isoleucine \\
LC & Median lethal concentration \\
MIC & Minimum inhibitory concentration \\
NMR & Nuclear magnetic resonance \\
NCI & National Cancer Institute \\
OSMAC & One strain many compounds \\
Phe & Phenylalanine \\
PKS & Polyketide synthase \\
Pro & Proline \\
SAR & Structure-activity relationship \\
S. aureu & Staphylococcus aureus \\
Tyr & Tyrosine \\
Val & Valine \\
&
\end{tabular}

\section{References}

1. Chiacchio, M.A.; Lanza, G.; Chiacchio, U.; Giofrè, S.; Romeo, R.; Iannazzo, D.; Legnani, L. Oxazole-based compounds as anticancer agents. Curr. Med. Chem. 2020, 26, 7337-7371. [CrossRef] [PubMed]

2. Zhang, H.Z.; Zhao, Z.L.; Zhou, C.H. Recent advance in oxazole-based medicinal chemistry. Eur. J. Med. Chem. 2018, 144, 444-492. [CrossRef]

3. Zhang, Y.X.; Hou, S.Y.; Zhang, M.Y.; Wu, Y.Y. Research progress in biosynthesis of five-membered heterocyclic rings in natural products. J. Microbiol. 2019, 39, 1-12. (In Chinese)

4. Kakkar, S.; Narasimhan, B. A comprehensive review on biological activities of oxazole derivatives. BMC Chem. 2019, 13, 1-24. [CrossRef]

5. Mhlongo, J.T.; Brasil, E.; De La Torre, B.G.; Albericio, F. Naturally occurring oxazole-containing peptides. Mar. Drugs 2020, 18, 203. [CrossRef]

6. N’Diaye, I.; Guella, G.; Chiasera, G.; Mancini, I.; Pietra, F. Almazole A and almazole B, unusual marine alkaloids of an unidentified red seaweed of the family delesseriaceae from the coasts of Senegal. Tetrahedron Lett. 1994, 35, 4827-4830. [CrossRef]

7. Guella, G.; Mancini, I.; Pietra, F. Almazole C, a new indole alkaloid bearing an unusually 2,5-disubstituted oxazole moiety, and its putative biogenetic peptidic precursors, from a Senegalese delesseriacean seaweed. Helvetica Chimica Acta 1994, 77, 1999-2006. [CrossRef]

8. N'Diaye, I.; Guella, G.; Mancini, I.; Pietra, F. Almazole D. a new type of antibacterial 2,5-disubstituted oxazolic dipeptide from a red alga of the coast of Senegal. Tetrahedron Lett. 1996, 37, 3049-3050. [CrossRef]

9. Molina, P.; Fresneda, P.; Castañeda, M.; Blug, M. Iminophosphorane-based preparation of 2,5-disubstituted oxazole derivatives: Synthesis of the marine alkaloid almazole C. Synlett 2007, 2007, 324-326. [CrossRef]

10. Miyake, F.; Hashimoto, M.; Tonsiengsom, S.; Yakushijin, K.; Horne, D.A. Synthesis of 5-(3-indolyl)oxazole natural products. Structure revision of almazole D. Tetrahedron 2010, 66, 4888-4893. [CrossRef]

11. Shin, H.J.; Jeong, H.S.; Lee, H.S.; Park, S.K.; Kim, H.M.; Kwon, H.J. Isolation and structure determination of streptochlorin, an antiproliferative agent from a marine-derived Streptomyces sp. 04DH110. J. Microbiol. Biotechnol. 2007, 17, 1403-1406. [CrossRef]

12. Takahashi, S.; Matsunaga, T.; Hasegawa, C.; Saito, H.; Fujita, D.; Kiuchi, F.; Tsuda, Y. Martefragin A, a novel indole alkaloid isolated from red alga, inhibits lipid peroxidation. Chem. Pharm. Bull. 1998, 46, 1527-1529. [CrossRef] [PubMed]

13. Choi, I.K.; Shin, H.J.; Lee, H.S.; Kwon, H.J. Streptochlorin, a marine natural product, inhibits NF-kB activation and suppresses angiogenesis in vitro. J. Microbiol. Biotechnol. 2007, 17, 1338-1343. [PubMed] 
14. Zhang, M.Z.; Jia, C.Y.; Gu, Y.C.; Mulholland, N.; Turner, S.; Beattie, D.; Zhang, W.H.; Yang, G.F.; Clough, J. Synthesis and antifungal activity of novel indole-replaced streptochlorin analogues. Eur. J. Med. Chem. 2017, 126, 669-674. [CrossRef]

15. Mueller, L.G., Jr.; Chao, A.; Alwedi, E.; Natrajan, M.; Fleming, F.F. Oxazole synthesis by sequential asmic-ester condensations and sulfanyl-lithium exchange-trapping. Org. Lett. 2021, 23, 1500-1503. [CrossRef] [PubMed]

16. Nishida, A.; Fuwa, M.; Fujikawa, Y.; Nakahata, E.; Furuno, A.; Nakagawa, M. First total synthesis of martefragin A, a potent inhibitor of lipid peroxidation isolated from sea alga. Tetrahedron Lett. 1998, 39, 5983-5986. [CrossRef]

17. Guella, G.; N’Diaye, I.; Fofana, M.; Mancini, I. Isolation, synthesis and photochemical properties of almazolone, a new indole alkaloid from a red alga of Senegal. Tetrahedron 2006, 62, 1165-1170. [CrossRef]

18. Schneider, Y.; Jenssen, M.; Isaksson, J.; Hansen, K.O.; Andersen, J.H.; Hansen, E.H. Bioactivity of serratiochelin A, a sidero-phore isolated from a co-culture of Serratia sp. and Shewanella sp. Microorganisms 2020, 8, 1042. [CrossRef]

19. Motohashi, K.; Takagi, M.; Shin-Ya, K. Tetrapeptides possessing a unique skeleton, JBIR-34 and JBIR-35, isolated from a spongederived actinomycete, Streptomyces sp. Sp080513GE-23. J. Nat. Prod. 2010, 73, 226-228. [CrossRef]

20. Muliandi, A.; Katsuyama, Y.; Sone, K.; Izumikawa, M.; Moriya, T.; Hashimoto, J.; Kozone, I.; Takagi, M.; Shin-Ya, K.; Ohnishi, Y. Biosynthesis of the 4-methyloxazoline-containing nonribosomal peptides, JBIR-34 and -35, in Streptomyces sp. Sp080513GE-23. Chem. Biol. 2014, 21, 923-934. [CrossRef]

21. Nielsen, A.; Mansson, M.; Wietz, M.; Varming, A.N.; Phipps, R.K.; Larsen, T.O.; Gram, L.; Ingmer, H. Nigribactin, a novel siderophore from Vibrio nigripulchritudo, modulates Staphylococcus aureus virulence gene expression. Mar. Drugs 2012, 10, 2584-2595. [CrossRef] [PubMed]

22. Rudi, A.; Stein, Z.; Green, S.; Goldberg, I.; Kashman, Y.; Benayahu, Y.; Schleyer, M. Phorbazoles A-D, novel chlorinated phenylpyrrolyloxazoles from the marine sponge phorbas aff. clathrata. Tetrahedron Lett. 1994, 35, 2589-2592. [CrossRef]

23. Guttormsen, Y.; Fairhurst, M.E.; Pandey, S.K.; Isaksson, J.; Haug, B.E.; Bayer, A. Total synthesis of phorbazole B. Molecules 2020, 25, 4848. [CrossRef] [PubMed]

24. Nuzzo, G.; Ciavatta, M.L.; Kiss, R.; Mathieu, V.; Leclercqz, H.; Manzo, E.; Villani, G.; Mollo, E.; Lefranc, F.; D’Souza, L.; et al. Chemistry of the nudibranch Aldisa andersoni: Structure and biological activity of phorbazole metabolites. Mar. Drugs 2012, 10, 1799-1811. [CrossRef] [PubMed]

25. Oku, N.; Adachi, K.; Matsuda, S.; Kasai, H.; Takatsuki, A.; Shizuri, Y. Ariakemicins A and B, novel polyketide-peptide antibi-otics from a marine gliding bacterium of the genus Rapidithrix. Org. Lett. 2008, 10, 2481-2484. [CrossRef] [PubMed]

26. Hansen, K.; Andersen, J.H.; Bayer, A.; Pandey, S.K.; Lorentzen, M.; Jørgensen, K.B.; Sydnes, M.O.; Guttormsen, Y.; Baumann, M.; Koch, U.; et al. Kinase chemodiversity from the arctic: The breitfussins. J. Med. Chem. 2019, 62, 10167-10181. [CrossRef]

27. Hanssen, K.; Schuler, B.; Williams, A.; Demissie, T.B.; Hansen, E.; Andersen, J.H.; Svenson, J.; Blinov, K.; Repisky, M.; Mohn, F.; et al. A combined atomic force microscopy and computational approach for the structural elucidation of breitfussin A and B: highly modified halogenated dipeptides from Thuiaria breitfussi. Angew. Chem. Int. Ed. 2012, 51, 12238-12241. [CrossRef] [PubMed]

28. Pandey, S.K.; Guttormsen, Y.; Haug, B.E.; Hedberg, C.; Bayer, A. A concise total synthesis of breitfussin A and B. Org. Lett. 2014, 17, 122-125. [CrossRef]

29. Kanoh, K.; Matsuo, Y.; Adachi, K.; Imagawa, H.; Nishizawa, M.; Shizuri, Y. Mechercharmycins A and B, cytotoxic substances from marine-derived Thermoactinomyces sp. YM3-251. J. Antibiot. 2005, 58, 289-292. [CrossRef]

30. Zhang, J.; Polishchuk, E.A.; Chen, J.; Ciufolini, M.A. Development of an oxazole conjunctive reagent and application to the total synthesis of siphonazoles. J. Org. Chem. 2009, 74, 9140-9151. [CrossRef] [PubMed]

31. Linder, J.; Moody, C.J. The total synthesis of siphonazole, a structurally unusual bis-oxazole natural product. Chem. Commun. 2007, 1508-1509. [CrossRef]

32. Fukuhara, K.; Takada, K.; Okada, S.; Matsunaga, S. Nazumazoles A-C, cyclic pentapeptides dimerized through a disulfide bond from the marine sponge Theonella swinhoei. Org. Lett. 2015, 17, 2646-2648. [CrossRef]

33. Fukuhara, K.; Takada, K.; Okada, S.; Matsunaga, S. Nazumazoles D-F, cyclic pentapeptides that inhibit chymotrypsin, from the marine sponge Theonella swinhoei. J. Nat. Prod. 2016, 79, 1694-1697. [CrossRef]

34. Fusetani, N.; Sugawara, T.; Matsunaga, S.; Hirota, H. Orbiculamide A: A novel cytotoxic cyclic peptide from a marine sponge Theonella sp. J. Am. Chem. Soc. 1991, 113, 7811-7812. [CrossRef]

35. Gunasekera, S.P.; Pomponi, S.A.; McCarthy, P. Discobahamins A and B, new peptides from the Bahamian deep water marine sponge Discodermia sp. J. Nat. Prod. 1994, 57, 79-83. [CrossRef] [PubMed]

36. Degnan, B.M.; Hawkins, C.J.; Lavin, M.F.; McCaffrey, E.J.; Parry, D.L.; Watters, D.J. Novel cytotoxic compounds from the ascidian Lissoclinum bistratum. J. Med. Chem. 1989, 32, 1354-1359. [CrossRef] [PubMed]

37. Perez, L.J.; Faulkner, D.J. Bistratamides E-J, modified cyclic hexapeptides from the Philippines ascidian Lissoclinum bistratum. J. Nat. Prod. 2003, 66, 247-250. [CrossRef] [PubMed]

38. Biard, J.F.; Roussakis, C.; Kornprobst, J.M.; Gouiffes-Barbin, D.; Verbist, J.F.; Cotelle, P.; Foster, M.; Ireland, C.M.; Debitus, C. Bistramides A, B, C, D, and K: A new class of bioactive cyclic polyethers from Lissoclinum bistratum. J. Nat. Prod. 1994, 57, 1336-1345. [CrossRef]

39. Foster, M.P.; Concepcion, G.P.; Caraan, G.B.; Ireland, C.M. Bistratamides C and D. Two new oxazole-containing cyclic hexapeptides isolated from a Philippine Lissoclinum bistratum ascidian. J. Org. Chem. 1992, 57, 6671-6675. [CrossRef] 
40. Urda, C.; Fernández, R.; Rodríguez, J.; Pérez, M.; Jiménez, C.; Cuevas, C. Bistratamides M and N, oxazole-thiazole containing cyclic hexapeptides isolated from Lissoclinum bistratum interaction of Zinc (II) with bistratamide K. Mar. Drugs 2017, 15, 209. [CrossRef] [PubMed]

41. Prinsep, M.R.; Moore, R.E.; Levine, I.A.; Patterson, G.M.L. Westiellamide, a bistratamide-related cyclic peptide from the BlueGreen Alga Westiellopsis prolifica. J. Nat. Prod. 1992, 55, 140-142. [CrossRef]

42. Ogino, J.; Moore, R.E.; Patterson, G.M.; Smith, C.D. Dendroamides, new cyclic hexapeptides from a blue-green alga. Multi-drugresistance reversing activity of dendroamide A. J. Nat. Prod. 1996, 59, 581-586. [CrossRef]

43. Rudi, A.; Chill, L.; Aknin, M.; Kashman, Y. Didmolamide A and B, two new cyclic hexapeptides from the marine ascidian Didemnum molle. J. Nat. Prod. 2003, 66, 575-577. [CrossRef]

44. Bertram, A.; Maulucci, N.; New, O.M.; Mohd Nor, S.M.; Pattenden, G. Synthesis of libraries of thiazole, oxazole and imidazolebased cyclic peptides from azole-based amino acids. A new synthetic approach to bistratamides and didmolamides. Org. Biomol. Chem. 2007, 5, 1541-1553. [CrossRef] [PubMed]

45. Ojika, M.; Nemoto, T.; Nakamura, M.; Yamada, K. Dolastatin E, a new cyclic hexapeptide isolated from the sea hare Dolabella auricularia. Tetrahedron Lett. 1995, 36, 5057-5058. [CrossRef]

46. Sone, H.; Kigoshi, H.; Yamada, K. Isolation and stereostructure of dolastatin I, a cytotoxic cyclic hexapeptide from the Japanese sea hare Dolabella auricularia. Tetrahedron 1997, 53, 8149-8154. [CrossRef]

47. Nakamura, M.; Shibata, T.; Nakane, K.; Nemoto, T.; Ojika, M.; Yamada, K. Stereochemistry and total synthesis of dolastatin E. Tetrahedron Lett. 1995, 36, 5059-5062. [CrossRef]

48. Kigoshi, H.; Yamada, S. Synthesis of dolastatin I, a cytotoxic cyclic hexapeptide from the sea hare Dolabella auricularia. Tetrahedron 1999, 55, 12301-12308. [CrossRef]

49. Kehraus, S.; König, G.M.; Wright, A.D.; Woerheide, G. Leucamide A: a new cytotoxic heptapeptide from the Australian sponge Leucetta microraphis. J. Org. Chem. 2002, 67, 4989-4992. [CrossRef]

50. Wang, W.L.; Yao, D.Y.; Gu, M.; Fan, M.Z.; Li, J.Y.; Xing, Y.C.; Nan, F.J. Synthesis and biological evaluation of novel bisheterocyclecontaining compounds as potential anti-influenza virus agents. Bioorg. Med. Chem. Lett. 2005, 15, 5284-5287. [CrossRef]

51. Wang, W.; Nan, F. First total synthesis of leucamide A. J. Org. Chem. 2003, 68, 1636-1639. [CrossRef] [PubMed]

52. Rudi, A.; Aknin, M.; Gaydou, E.M.; Kashman, Y. Four new cytotoxic cyclic hexa- and heptapeptides from the marine ascidian Didemnum molle. Tetrahedron 1998, 54, 13203-13210. [CrossRef]

53. Liu, Y.; He, P.; Zhang, Y.; Zhang, X.; Liu, J.; Du, Y. One-pot enantiomeric synthesis of thiazole-containing amino acids: Total synthesis of venturamides A and B. J. Org. Chem. 2018, 83, 3897-3905. [CrossRef] [PubMed]

54. Banker, R.; Carmeli, S. Tenuecyclamides A-D, cyclic hexapeptides from the cyanobacterium Nostoc spongiaeforme var. tenue. J. Nat. Prod. 1998, 61, 1248-1251. [CrossRef] [PubMed]

55. You, S.L.; Deechongkit, S.; Kelly, J.W. Solid-phase synthesis and stereochemical assignments of tenuecyclamides A-D employing heterocyclic amino acids derived from commercially available fmoc $\alpha$-amino acids. Org. Lett. 2004, 6, 2627-2630. [CrossRef] [PubMed]

56. Ziemert, N.; Ishida, K.; Quillardet, P.; Bouchier, C.; Hertweck, C.; deMarsac, N.T.; Dittmann, E. Microcyclamide biosynthesis in two strains of Microcystis aeruginosa: From structure to genes and vice versa. Appl. Environ. Microbiol. 2008, 74, 1791-1797. [CrossRef] [PubMed]

57. Raveh, A.; Moshe, S.; Evron, Z.; Flescher, E.; Carmeli, S. Novel thiazole and oxazole containing cyclic hexapeptides from a waterbloom of the cyanobacterium Microcystis sp. Tetrahedron 2010, 66, 2705-2712. [CrossRef]

58. Ishida, K.; Nakagawa, H.; Murakami, M. Microcyclamide, a cytotoxic cyclic hexapeptide from the cyanobacterium Microcystis aeruginosa. J. Nat. Prod. 2000, 63, 1315-1317. [CrossRef]

59. Houssen, W.; Koehnke, J.; Zollman, D.; Vendome, J.; Raab, A.; Smith, M.; Naismith, J.; Jaspars, M. The discovery of new cyanobactins from Cyanothece PCC 7425 defines a new signature for processing of patellamides. ChemBioChem 2012, 13, 2683-2689. [CrossRef] [PubMed]

60. Toske, S.G.; Fenical, W. Cyclodidemnamide: a new cyclic heptapeptide from the marine ascidian Didemnum Molle. Tetrahedron Lett. 1995, 36, 8355-8358. [CrossRef]

61. Tan, L.T.; Williamson, R.T.; Gerwick, W.H.; Watts, K.S.; McGough, K.; Jacobs, R. cis,cis- and trans,trans-ceratospongamide, new bioactive cyclic heptapeptides from the Indonesian red alga Ceratodictyon spongiosum and symbiotic sponge Sigmadocia symbiotica. J. Org. Chem. 2000, 65, 419-425. [CrossRef] [PubMed]

62. Wasylyk, J.M.; Biskupiak, J.E.; Costello, C.E.; Ireland, C.M. Cyclic peptide structures from the tunicate Ceratodictyon spongiosum by FAB mass spectrometry. J. Org. Chem. 1983, 48, 4445-4449. [CrossRef]

63. Degnan, B.M.; Hawkins, C.J.; Lavin, M.F.; McCaffrey, E.J.; Parry, D.L.; Brenk, A.L.V.D.; Watters, D.J. New cyclic peptides with cytotoxic activity from the ascidian Lissoclinum patella. J. Med. Chem. 1989, 32, 1349-1354. [CrossRef]

64. Schmitz, F.J.; Ksebati, M.B.; Chang, J.S.; Wang, J.L.; Hossain, M.B.; Van der Helm, D.; Engel, M.H.; Serban, A.; Silfer, J.A. Cyclic peptides from the ascidian Lissoclinum patella: Conformational analysis of patellamide D by X-ray analysis and molecular modeling. J. Org. Chem. 1989, 54, 3463-3472. [CrossRef]

65. Morris, L.A.; Bosch, J.K.V.D.; Versluis, K.; Thompson, G.S.; Jaspars, M. Structure determination and MSn analysis of two new lissoclinamides isolated from the Indo-Pacific ascidian Lissoclinum patella: NOE restrained molecular dynamics confirms the absolute stereochemistry derived by degradative methods. Tetrahedron 2000, 56, 8345-8353. [CrossRef] 
66. Hawkins, C.J.; Lavin, M.F.; Marshall, K.A.; van den Brenk, A.L.; Watters, D.J. Structure-activity relationships of the lissoclinaides: Cytotoxic cyclic peptides from the ascidian Lissoclinum patella. J. Med. Chem. 1990, 33, 1634-1638. [CrossRef] [PubMed]

67. Ireland, C.; Scheuer, P.J. Ulicyclamide and ulithiacyclamide, two new small peptides from a marine tunicate. J. Am. Chem. Soc. 1980, 102, 5688-5691. [CrossRef]

68. Wipf, P.; Fritch, P.C.; Geib, S.J.; Sefler, A.M. Conformational studies and structure-activity analysis of lissoclinamide 7 and related cyclopeptide alkaloids. J. Am. Chem. Soc. 1998, 120, 4105-4112. [CrossRef]

69. Dalisay, D.S.; Rogers, E.W.; Edison, A.; Molinski, T.F. Structure elucidation at the nanomole scale. 1. Trisoxazole macrolides and thiazole-containing cyclic peptides from the nudibranch Hexabranchus sanguineus. J. Nat. Prod. 2009, 72, 732-738. [CrossRef] [PubMed]

70. Singh, E.K.; Ramsey, D.M.; McAlpine, S.R. Total synthesis of trans, trans-sanguinamide B and conformational isomers. Org. Lett. 2012, 14, 1198-1201. [CrossRef]

71. Erickson, K.L.; Gustafson, K.R.; Milanowski, D.J.; Pannell, L.K.; Klose, J.R.; Boyd, M.R. Myriastramides A-C, new modified cyclic peptides from the Philippines marine sponge Myriastra clavosa. Tetrahedron 2003, 59, 10231-10238. [CrossRef]

72. Guan, L.L.; Sera, Y.; Adachi, K.; Nishida, F.; Shizuri, Y. Isolation and evaluation of nonsiderophore cyclic peptides from ma-rine sponges. Biochem. Biophys. Res. Commun. 2001, 283, 976-981. [CrossRef]

73. Sera, Y.; Adachi, K.; Fujii, K.; Shizuri, Y. Isolation of haliclonamides: New peptides as antifouling substances from a marine sponge species, Haliclona. Mar. Biotechnol. 2002, 4, 441-446. [CrossRef] [PubMed]

74. Festa, C.; De Marino, S.; D’Auria, M.V.; Monti, M.C.; Bucci, M.; Vellecco, V.; Debitus, C.; Zampella, A. Anti-inflammatory cyclopeptides from the marine sponge Theonella swinhoei. Tetrahedron 2012, 68, 2851-2857. [CrossRef]

75. Asano, A.; Yamada, T.; Taniguchi, T.; Sasaki, M.; Yoza, K.; Doi, M. Ascidiacyclamides containing oxazoline and thiazole motifs assume square conformations and show high cytotoxicity. J. Pept. Sci. 2018, 24, 3120. [CrossRef] [PubMed]

76. Fu, X.; Do, T.; Schmitz, F.J.; Andrusevich, V.; Engel, M.H. New cyclic peptides from the ascidian Lissoclinum patella. J. Nat. Prod. 1998, 61, 1547-1551. [CrossRef]

77. Fu, X.; Su, J.Y.; Zeng, L.M. Prepatellamide A, a new cyclic peptide from the ascidian Lissoclinum patella. Sci. China Ser. B 2000, 43, 643-648. [CrossRef]

78. Sesin, D.F.; Gaskell, S.J.; Ireland, C.M. The chemistry of Lissoclinum patella. Bull. Soc. Chim. Belq. 1986, 95, 853-867. [CrossRef]

79. Nam, S.J.; Kauffman, C.; Jensen, P.R.; Moore, C.E.; Rheingold, A.L.; Fenical, W. Actinobenzoquinoline and actinophenanthrolines A-C, unprecedented alkaloids from a marine actinobacterium. Org. Lett. 2015, 17, 3240-3243. [CrossRef]

80. In, Y.; Doi, M.; Inoue, M.; Ishida, T.; Hamada, Y.; Shioiri, T. Patellamide A, a cytotoxic cyclic peptide from the ascidian Lissoclinum patella. Acta Crystallogr. C 1994, 50, 432-434. [CrossRef]

81. Ireland, C.M.; Durso, A.R.; Newman, R.A.; Hacker, M.P. Antineoplastic cyclic peptides from the marine tunicate Lissoclinum patella. J. Org. Chem. 1982, 47, 1807-1811. [CrossRef]

82. Williams, A.B.; Jacobs, R.S. A marine natural product, patellamide D, reverses multidrug resistance in a human leukemic cell line. Cancer Lett. 1993, 71, 97-102. [CrossRef]

83. McDonald, L.A.; Ireland, C.M. Patellamide E: a new cyclic peptide from the ascidian Lissoclinum patella. J. Nat. Prod. 1992, 55, 376-379. [CrossRef] [PubMed]

84. Rashid, M.A.; Gustafson, K.R.; Cardellina, J.H.; Boyd, M.R. Patellamide F, a new cytotoxic cyclic peptide from the colonial ascidian Lissoclinum patella. J. Nat. Prod. 1995, 58, 594-597. [CrossRef] [PubMed]

85. Schmidt, E.W.; Nelson, J.T.; Rasko, D.A.; Sudek, S.; Eisen, J.A.; Haygood, M.G.; Ravel, J. Patellamide A and C biosynthesis by a microcin-like pathway in Prochloron didemni, the cyanobacterial symbiont of Lissoclinum patella. Proc. Natl. Acad. Sci. USA 2005, 102, 7315-7320. [CrossRef]

86. Martin, J.; Sousa, T.D.S.; Crespo, G.; Palomo, S.; González, I.; Tormo, J.R.; De La Cruz, M.; Anderson, M.; Hill, R.T.; Vicente, F.; et al. Kocurin, the true structure of PM181104, an anti-methicillin-resistant Staphylococcus aureus (MRSA) thiazolyl peptide from the marine-derived bacterium Kocuria palustris. Mar. Drugs 2013, 11, 387-398. [CrossRef] [PubMed]

87. Linares-Otoya, L.; Linares-Otoya, V.; Armas-Mantilla, L.; Blanco, C.; Crüsemann, M.; Ganoza-Yupanqui, M.L.; Campos-Florián, J.V.; König, G.M.; Schäberle, T.F. Identification and heterologous expression of the kocurin biosynthetic gene cluster. Microbiology 2017, 163, 1409-1414. [CrossRef] [PubMed]

88. Matsuo, Y.; Kanoh, K.; Yamori, T.; Kasai, H.; Katsuta, A.; Adachi, K.; Shin-Ya, K.; Shizuri, Y. Urukthapelstatin A, a novel cytotoxic substance from marine-derived Mechercharimyces asporophorigenens YM11-542. I. Fermentation, isolation and biological activities. J. Antibiot. 2007, 60, 251-255. [CrossRef] [PubMed]

89. Schwenk, S.; Ronco, C.; Oberheide, A.; Arndt, H.D. Biomimetic synthesis of urukthapelstatin A by Aza-Wittig ring contraction. Eur. J. Org. Chem. 2016, 2016, 4795-4799. [CrossRef]

90. Oberheide, A.; Schwenk, S.; Ronco, C.; Semmrau, L.M.; Görls, H.; Arndt, H.-D. Synthesis, structure, and cytotoxicity of urukthapelstatin A polyazole cyclopeptide analogs. Eur. J. Org. Chem. 2019, 2019, 4320-4326. [CrossRef]

91. Engelhardt, K.; Degnes, K.F.; Zotchev, S.B. Isolation and characterization of the gene cluster for biosynthesis of the thiopeptide antibiotic TP-1161. Appl. Environ. Microbiol. 2010, 76, 7093-7101. [CrossRef] [PubMed]

92. Engelhardt, K.; Degnes, K.F.; Kemmler, M.; Bredholt, H.; Fjærvik, E.; Klinkenberg, G.; Sletta, H.; Ellingsen, T.E.; Zotchev, S.B. Production of a new thiopeptide antibiotic, TP-1161, by a marine Nocardiopsis species. Appl. Environ. Microbiol. 2010, 76, 4969-4976. [CrossRef] [PubMed] 
93. Nogle, L.M.; Marquez, A.B.L.; Gerwick, W.H. Wewakazole, a novel cyclic dodecapeptide from a Papua new guinea Lyngbya majuscula. Org. Lett. 2002, 5, 3-6. [CrossRef]

94. Long, B.; Zhang, J.; Tang, X.; Wu, Z. Total synthesis of wewakazole B. Org. Biomol. Chem. 2016, 14, 9712-9715. [CrossRef]

95. Lindquist, N.; Fenical, W.; Van Duyne, G.D.; Clardy, J. Isolation and structure determination of diazonamides A and B, unusual cytotoxic metabolites from the marine ascidian Diazona chinensis. J. Am. Chem. Soc. 1991, 113, 2303-2304. [CrossRef]

96. Fernández, R.; Martín, M.J.; Rodríguez-Acebes, R.; Reyes, F.; Francesch, A.; Cuevas, C. Diazonamides C-E, new cytotoxic metabolites from the ascidian Diazona sp. Tetrahedron Lett. 2008, 49, 2283-2285. [CrossRef]

97. Nicolaou, K.C.; Chen, D.Y.-K.; Huang, X.; Ling, T.; Bella, M.; Snyder, S.A. Chemistry and biology of diazonamide A: First total synthesis and confirmation of the true structure. J. Am. Chem. Soc. 2004, 126, 12888-12896. [CrossRef]

98. Williams, D.E.; Moore, R.E.; Paul, V.J. The structure of ulithiacyclamide B. Antitumor evaluation of cyclic peptides and macrolides from Ceratodictyon spongiosum. J. Nat. Prod. 1989, 52, 732-739. [CrossRef] [PubMed]

99. Komatsu, N.; Nakauch, H.; Miwa, A.; Ishihara, T.; Eguchi, M.; Moroi, M.; Okada, M.; Sato, Y.; Wada, H.; Yawata, Y.; et al. Establishment and characterization of a human leukemic cell line with megakaryocytic features: Dependency on granulocyte-macrophage colonystimulating factor, interleukin 3, or erythropoietin for growth and survival. Cancer Res. 1991, 51, 341-348. [CrossRef]

100. Degruyter, J.N.; Maio, W.A. The taumycin A macrocycle: Asymmetric total synthesis and revision of relative stereochemistry. Org. Lett. 2014, 16, 5196-5199. [CrossRef] [PubMed]

101. Tada, H.; Tozyo, T.; Terui, Y.; Hayashi, F. Discokiolides. Cytotoxic cyclic depsipeptides from the marine sponge Discodermia kiiensis. Chem. Lett. 1992, 21, 431-434. [CrossRef]

102. Molinski, T.F. Absolute configuration of phorboxazoles A and B from the marine sponge, Phorbas sp. 2. C43 and complete stereochemistry. Tetrahedron Lett. 1996, 37, 7879-7880. [CrossRef]

103. Dalisay, D.S.; Molinski, T.F. Structure elucidation at the nanomole scale. 2. Hemi-phorboxazole A from Phorbas sp. Org. Lett. 2009, 11, 1967-1970. [CrossRef]

104. Sandler, J.S.; Colin, P.L.; Kelly, M.; Fenical, W. Cytotoxic macrolides from a new species of the deep-water marine sponge Leiodermatium. J. Org. Chem. 2006, 71, 7245-7251. [CrossRef] [PubMed]

105. Bishara, A.; Rudi, A.; Aknin, M.; Neumann, D.; Ben-Califa, N.; Kashman, Y. Salarin C, a new cytotoxic sponge-derived nitrogenous macrolide. Tetrahedron Lett. 2008, 49, 4355-4358. [CrossRef]

106. Bishara, A.; Rudi, A.; Aknin, M.; Neumann, D.; Ben-Califa, N.; Kashman, Y. Salarins D-J, seven new nitrogenous macrolides from the Madagascar sponge Fascaplysinopsis sp. Tetrahedron 2010, 66, 4339-4345. [CrossRef]

107. Kobayashi, J.; Kondo, K.; Ishibashi, M.; Walchli, M.R.; Nakamura, T. Theonezolide A: A novel polyketide natural product from the Okinawan marine sponge Theonella sp. J. Am. Chem. Soc. 1993, 115, 6661-6665. [CrossRef]

108. Kondo, K.; Ishibashi, M.; Kobayashi, J. Isolation and structures of theonezolides B and C from the Okinawan marine sponge Theonella sp. Tetrahedron 1994, 50, 8355-8362. [CrossRef]

109. Rho, M.C.; Park, Y.H.; Sasaki, S.; Ishibashi, M.; Kondo, K.; Kobayashi, J.; Ohizumi, Y. The mode of rabbit platelet shape change and aggregation induced by theonezolide-A, a novel polyketide macrolide, isolated from the Okinawan marine sponge Theonella sp. Can. J. Physiol. Pharmacol. 1996, 74, 193-199. [CrossRef] [PubMed]

110. Petchprayoon, C.; Asato, Y.; Higa, T. Four new kabiramides from the Thai sponge, Pachastrissa nux. Heterocycles 2006, 69, 447. [CrossRef]

111. Kobayashi, J.; Tsuda, M.; Fuse, H.; Sasaki, T.; Mikami, Y. Halishigamides A-D, new cytotoxic oxazole-containing metabolites from Okinawan sponge Halichondria sp. J. Nat. Prod. 1997, 60, 150-154. [CrossRef]

112. Rashid, M.A.; Gustafson, K.R.; Cardellina, J.H.; Boyd, M.R. Mycalolides D and E, new cytotoxic macrolides from a collection of the stony coral Tubastrea faulkneri. J. Nat. Prod. 1995, 58, 1120-1125. [CrossRef]

113. Klenchin, V.A.; Allingham, J.S.; King, R.; Tanaka, J.; Marriott, G.; Rayment, I. Trisoxazole macrolide toxins mimic the binding of actin-capping proteins to actin. Nat. Struct. Biol. 2003, 10, 1058-1063. [CrossRef] [PubMed]

114. Roesener, J.A.; Scheuer, P.J. Ulapualide A and B, extraordinary antitumor macrolides from nudibranch eggmasses. J. Am. Chem. Soc. 1986, 108, 846-847. [CrossRef]

115. Suo, R.; Takada, K.; Kohtsuka, H.; Ise, Y.; Okada, S.; Matsunaga, S. Miuramides A and B, trisoxazole macrolides from a Mycale sp. marine sponge that induce a protrusion phenotype in cultured mammalian cells. J. Nat. Prod. 2018, 81, 1108-1112. [CrossRef] [PubMed]

116. Matsunaga, S.; Liu, P.; Celatka, C.A.; Panek, J.S.; Fusetani, N. Relative and absolute stereochemistry of mycalolides, bioactive macrolides from the marine sponge Mycale magellanica. J. Am. Chem. Soc. 1999, 121, 5605-5606. [CrossRef]

117. Fusetani, N.; Yasumuro, K.; Matsunaga, S.; Hashimoto, K. Mycalolides A-C, hybrid macrolides of ulapualides and halichondramide, from a sponge of the genus Mycale. Tetrahedron Lett. 1989, 30, 2809-2812. [CrossRef]

118. Kobayashi, J.; Murata, O.; Shigemori, H.; Sasaki, T. Jaspisamides A-C, new cytotoxic macrolides from the Okinawan sponge Jaspis sp. J. Nat. Prod. 1993, 56, 787-791. [CrossRef]

119. Sirirak, T.; Kittiwisut, S.; Janma, C.; Yuenyongsawad, S.; Suwanborirux, K.; Plubrukarn, A. Kabiramides J and K, trisoxazole macrolides from the sponge Pachastrissa nux. J. Nat. Prod. 2011, 74, 1288-1292. [CrossRef] [PubMed]

120. Youngsaye, W.; Lowe, J.T.; Pohlki, F.; Ralifo, P.; Panek, J.S. Total synthesis and stereochemical reassignment of (+)-neopeltolide. Angew. Chem. Int. Ed. 2007, 46, 9211-9214. [CrossRef]

121. Custar, D.W.; Zabawa, T.P.; Hines, J.; Crews, C.M.; Scheidt, K.A. Total synthesis and structure-activity investigation of the marine natural product neopeltolide. J. Am. Chem. Soc. 2009, 131, 12406-12414. [CrossRef] [PubMed] 
122. D'Ambrosio, M.; Guerriero, A.; Debitus, C.; Pietra, F. Leucascandrolide A, a new type of macrolide: The first powerfully bio-active metabolite of calcareous sponges (Leucascandra caveolata, a new genus from the coral sea). Helv. Chim. Acta 1996, 79, 51-60. [CrossRef]

123. Ulanovskaya, O.A.; Janjic, J.; Suzuki, M.; Sabharwal, S.S.; Schumacker, P.T.; Kron, S.J.; Kozmin, S.A. Synthesis enables identification of the cellular target of leucascandrolide A and neopeltolide. Nat. Chem. Biol. 2008, 4, 418-424. [CrossRef] [PubMed]

124. Oku, N.; Takada, K.; Fuller, R.W.; Wilson, J.A.; Peach, M.L.; Pannell, L.K.; McMahon, J.B.; Gustafson, K.R. Isolation, structural elucidation, and absolute stereochemistry of enigmazole A, a cytotoxic phosphomacrolide from the Papua new guinea marine sponge Cinachyrella enigmatica. J. Am. Chem. Soc. 2010, 132, 10278-10285. [CrossRef]

125. Sakurai, K.; Sakamoto, K.; Sasaki, M.; Fuwa, H. Unified total synthesis of (-)-enigmazole A and (-)-15-O-Methylenigmazole A. Chem. Asian. J. 2020, 15, 3494-3502. [CrossRef] [PubMed]

126. Kato, Y.; Fusetani, N.; Matsunaga, S.; Hashimoto, K.; Fujita, S.; Furuya, T. Bioactive marine metabolites. Part 16. Calyculin A. A novel antitumor metabolite from the marine sponge Discodermia calyx. J. Am. Chem. Soc. 1986, 108, 2780-2781. [CrossRef]

127. Matsunaga, S.; Wakimoto, T.; Fusetani, N. Isolation of four new calyculins from the marine sponge Discodermia calyx. J. Org. Chem. 1997, 62, 9388. [CrossRef]

128. Matsunaga, S.; Fujiki, H.; Sakata, D.; Fusetani, N. ChemInform Abstract: Calyculins E, F, G, and H, Additional inhibitors of protein phosphatases 1 and 2A, from the marine sponge Discodermia calyx. Tetrahedron 2010, 22, 2999-3006. [CrossRef]

129. Kehraus, S.; König, G.M.; Wright, A.D. A new cytotoxic calyculinamide derivative, geometricin A, from the Australian sponge Luffariella geometrica. J. Nat. Prod. 2002, 65, 1056-1058. [CrossRef] [PubMed]

130. Matsunaga, S.; Wakimoto, T.; Fusetani, N.; Suganuma, M. Isolation of dephosphonocalyculin a from the marine sponge, Discodermia calyx. Tetrahedron Lett. 1997, 38, 3763-3764. [CrossRef]

131. Fu, X.; Schmitz, F.J.; Kelly-Borges, M.; McCready, A.T.L.; Holmes, C.F.B. Clavosines A-C from the marine sponge Myriastra clavosa: Potent cytotoxins and inhibitors of protein phosphatases 1 and 2A. J. Org. Chem. 1998, 63, 7957-7963. [CrossRef]

132. Hou, S.Y.; Zhang, M.Y.; Wang, H.D.; Zhang, Y.X. Characterization of the biosynthesis gene cluster and oxazole ring formation enzyme for inthomycins in Streptomyces sp. strain SYP-A7193. Appl. Environ. Microbiol. 2020, 86, 1-44. [CrossRef]

133. Webb, M.R.; Donald, C.; Taylor, R.J.K. A general route to the Streptomyces-derived inthomycin family: the first synthesis of (+)-inthomycin B. Tetrahedron Lett. 2006, 47, 549-552. [CrossRef]

134. Shin, J.; Lee, H.S.; Kim, J.-Y.; Shin, H.J.; Ahn, J.W.; Paul, V.J. New macrolides from the sponge Chondrosia corticata. J. Nat. Prod. 2004, 67, 1889-1892. [CrossRef]

135. Higa, T.; Tanaka, J.I.; Kitamura, A.; Koyama, T.; Takahashia, M.; Uchida, T. Bioactive compounds from marine sponges. Pure Appl. Chem. 1994, 66, 2227-2230. [CrossRef]

136. Ichiba, T.; Yoshida, W.Y.; Scheuer, P.J.; Higa, T.; Gravalos, D.G. Hennoxazoles, bioactive bisoxazoles from a marine sponge. J. Am. Chem. Soc. 1991, 113, 3173-3174. [CrossRef]

137. Takaishi, S.; Tuchiya, N.; Sato, A.; Negishi, T.; Takamatsu, Y.; Matsushita, Y.; Watanabe, T.; Iijima, Y.; Haruyama, H.; Kinoshita, T.; et al. B-90063, a novel endothelin converting enzyme inhibitor isolated from a new marine bacterium, Blastobacter sp. SANK 71894. J. Antibiot. 1998, 51, 805-815. [CrossRef] [PubMed]

138. Fernández, R.; Dherbomez, M.; Letourneux, Y.; Nabil, M.; Verbist, A.J.F.; Biard§, J.F. Antifungal metabolites from the marine sponge Pachastrissa sp.: New bengamide and bengazole derivatives. J. Nat. Prod. 1999, 62, 678-680. [CrossRef] [PubMed]

139. Mulder, R.J.; Shafer, C.M.; Dalisay, D.S.; Molinski, T.F. Synthesis and structure-activity relationships of bengazole A analogs. Bioorganic Med. Chem. Lett. 2009, 19, 2928-2930. [CrossRef] [PubMed]

140. Zhao, B.B.; Guo, H.J.; Liu, Y.; Luo, X.Y.; Yang, S.X.; Wang, Y.T.; Leng, X.; Mo, C.F.; Zou, Q. K313, a novel benzoxazole derivative, exhibits anti-inflammatory properties via inhibiting GSK3 $\beta$ activity in LPS-induced RAW264.7 macrophages. J. Cell Biochem. 2018, 119, 5382-5390. [CrossRef] [PubMed]

141. Demmer, C.S.; Bunch, L. Benzoxazoles and oxazolopyridines in medicinal chemistry studies. Eur. J. Med. Chem. 2015, 97, 778-785. [CrossRef] [PubMed]

142. Hwang, I.H.; Oh, J.; Zhou, W.; Park, S.; Kim, J.H.; Chittiboyina, A.; Ferreira, D.; Song, G.Y.; Oh, S.; Na, M.; et al. Cytotoxic activity of rearranged drimane meroterpenoids against colon cancer cells via down-regulation of $\beta$-catenin expression. J. Nat. Prod. 2015, 78, 453-461. [CrossRef] [PubMed]

143. Wang, J.; Mu, F.R.; Jiao, W.-H.; Huang, J.; Hong, L.L.; Yang, F.; Xu, Y.; Wang, S.P.; Sun, F.; Lin, H.W. Meroterpenoids with protein tyrosine phosphatase 1B inhibitory activity from a Hyrtios sp. marine sponge. J. Nat. Prod. 2017, 80, 2509-2514. [CrossRef] [PubMed]

144. Daletos, G.; deVoogd, N.J.; Müller, W.E.G.; Wray, V.; Lin, W.; Feger, D.; Kubbutat, M.; Aly, A.H.; Proksch, P. Cytotoxic and protein kinase inhibiting nakijiquinones and nakijiquinols from the sponge Dactylospongia metachromia. J. Nat. Prod. 2014, 77, 218-226. [CrossRef]

145. Ovenden, S.P.B.; Nielson, J.L.; Liptrot, C.H.; Willis, R.H.; Tapiolas, D.M.; Wright, A.D.; Motti, C.A. Sesquiterpene benzoxazoles and sesquiterpene quinones from the marine sponge Dactylospongia elegans. J. Nat. Prod. 2011, 74, 65-6810. [CrossRef]

146. Takeda, Y.; Nakai, K.; Narita, K.; Katoh, T. A novel approach to sesquiterpenoid benzoxazole synthesis from marine sponges: Nakijinols A, B and E-G. Org. Biomol. Chem. 2018, 16, 3639-3647. [CrossRef]

147. Sun, M.; Zhang, X.; Hao, H.; Li, W.; Lu, C. Nocarbenzoxazoles A-G, benzoxazoles produced by halophilic Nocardiopsis lucen-tensis DSM 44048. J. Nat. Prod. 2015, 78, 2123-2127. [CrossRef] [PubMed]

148. Kim, T.; Lee, S.A.; Noh, T.; Choi, P.; Choi, S.J.; Song, B.G.; Kim, Y.; Park, Y.T.; Huh, G.; Kim, Y.J.; et al. Synthesis, structure revision, and cytotoxicity of nocarbenzoxazole G. J. Nat. Prod. 2019, 82, 1325-1330. [CrossRef] [PubMed] 
149. Venkateswarlu, Y.; Reddy, N.S.; Ramesh, P.; Rao, J.V. Coixol: A bioactive principle from a marine sponge Oceanapia sp. Biochem. Syst. Ecol. 1999, 27, 519-520. [CrossRef]

150. Rodríguez, I.I.; Rodríguez, A.D. Homopseudopteroxazole, a new antimycobacterial diterpene alkaloid from Pseudopterogorgia elisabethae. J. Nat. Prod. 2003, 66, 855-857. [CrossRef]

151. Rodriguez, A.D.; Ramirez, C.; Rodriguez, I.I.; Gonzalez, E. Novel antimycobacterial benzoxazole alkaloids, from the west Indian sea whip Pseudopterogorgia elisabethae. Org. Lett. 1999, 1, 527-530. [CrossRef]

152. Georgantea, P.; Ioannou, E.; Evain-Bana, E.; Bagrel, D.; Martinet, N.; Vagias, C.; Roussis, V. Sesquiterpenes with inhibitory activity against CDC25 phosphatases from the soft coral Pseudopterogorgia rigida. Tetrahedron 2016, 72, 3262-3269. [CrossRef]

153. McCulloch, M.W.B.; Berrue, F.; Haltli, B.; Kerr, R.G. One-Pot syntheses of pseudopteroxazoles from pseudopterosins: A rapid route to non-natural congeners with improved antimicrobial activity. J. Nat. Prod. 2011, 74, 2250-2256. [CrossRef]

154. Zhang, X.; Fang, X.; Xu, M.; Lei, Y.; Wu, Z.; Hu, X. Enantioselective total synthesis of pseudopteroxazole and ileabethoxazole. Angew. Chem. Int. Ed. 2019, 58, 7845-7849. [CrossRef]

155. Genta-Jouve, G.; Francezon, N.; Puissant, A.; Auberger, P.; Vacelet, J.; Pérez, T.; Fontana, A.; Al Mourabit, A.; Thomas, O.P. Structure elucidation of the new citharoxazole from the Mediterranean deep-sea sponge Latrunculia (Biannulata) citharistae. Magn. Reson. Chem. 2011, 49, 533-536. [CrossRef] [PubMed]

156. Julianti, E.; Lee, J.H.; Liao, L.; Park, W.; Park, S.; Oh, D.C.; Oh, K.B.; Shin, J. New polyaromatic metabolites from a marine-derived fungus Penicillium sp. Org. Lett. 2013, 15, 1286-1289. [CrossRef] [PubMed]

157. Takahashi, Y.; Kubota, T.; Shibazaki, A.; Gonoi, T.; Fromont, J.; Kobayashi, J. Nakijinamines C-E, new heteroaromatic alkaloids from the sponge Suberites species. Org. Lett. 2011, 13, 3016-3019. [CrossRef] [PubMed]

158. Hohmann, C.; Schneider, K.; Bruntner, C.; Irran, E.; Nicholson, G.; Bull, A.T.; Jones, A.L.; Brown, R.; Stach, J.E.M.; Goodfellow, M.; et al. Caboxamycin, a new antibiotic of the benzoxazole family produced by the deep-sea strain Streptomyces sp. NTK 937. J. Antibiot. 2009, 62, 99-104. [CrossRef] [PubMed]

159. Tagawa, Y.; Koba, H.; Tomoike, K.; Sumoto, K. Synthesis of caboxamycin and its derivatives using eco-friendly oxidation. Heterocycles 2011, 83, 867. [CrossRef]

160. Losada, A.A.; Cano-Prieto, C.; Garcia-Salcedo, R.; Brana, A.F.; Mendez, C.; Salas, J.A.; Olano, C. Caboxamycin biosynthesis pathway and identification of novel benzoxazoles produced by cross-talk in Streptomyces sp. NTK 937. Microb. Biotechnol. 2017, 10, 873-885. [CrossRef] [PubMed]

161. Dattelbaum, J.D.; Singh, A.J.; Field, J.J.; Miller, J.H.; Northcote, P.T. The nitrogenous hamigerans: Unusual amino acid-derivatized aromatic diterpenoid metabolites from the New Zealand marine sponge Hamigera tarangaensis. J. Org. Chem. 2015, 80, 304-312. [CrossRef] [PubMed]

162. Liu, L.L.; Xu, Y.; Han, Z.; Li, Y.X.; Lu, L.; Lai, P.Y.; Zhong, J.L.; Guo, X.R.; Zhang, X.X.; Qian, P.Y. Four new antibacterial xanthones from the marine-derived actinomycetes Streptomyces caelestis. Mar. Drugs 2012, 10, 2571-2583. [CrossRef] [PubMed]

163. Susic, D.; Djordjevic, N.; Kentera, D. Hemodynamic effects of two ergot derivatives in the conscious spontaneously hyper-tensive rat. Pharmacology 1984, 29, 215-223. [CrossRef] [PubMed]

164. Zhang, H.; Zhao, Z.; Wang, H. Cytotoxic natural products from marine sponge-derived microorganisms. Mar. Drugs 2017, 15, 68. [CrossRef] [PubMed]

165. Kamat, S.; Kumari, M.; Taritla, S.; Jayabaskaran, C. Endophytic fungi of marine alga from Konkan coast, India-A rich source of bioactive material. Front. Mar. Sci. 2020, 7, 1-16. [CrossRef]

166. Chen, S.; Cai, R.; Liu, Z.; Cui, H.; She, Z. Secondary metabolites from mangrove-associated fungi: Source, chemistry and bioactivities. Nat. Prod. Rep. 2021. [CrossRef] [PubMed]

167. Ramesh, C.; Tulasi, B.R.; Raju, M.; Thakur, N.; Dufosse, L. Marine natural products from tunicates and their associated mi-crobes. Mar. Drugs 2021, 19, 308. [CrossRef] [PubMed]

168. Atanasov, A.G.; Zotchev, S.B.; Dirsch, V.M.; the International Natural Product Sciences Taskforce; Supuran, C.T. Natural products in drug discovery: Advances and opportunities. Nat. Rev. Drug Discov. 2021, 20, 200-216. [CrossRef] [PubMed] 